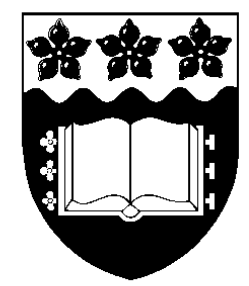

University of Wollongong

Economics Working Paper Series 2003

http://www.uow.edu.au/commerce/econ/wplist.html

The Budget Deficit and Economic Performance:

A Survey

Ali Salman Saleh

WP 03-12

September 2003 


\title{
The Budget Deficit and Economic Performance: A Survey
}

\author{
By \\ Ali Salman Saleh* \\ School of Economics and Information Systems \\ University of Wollongong \\ NSW Australia
}

Tel.: $\quad+61242213045$

Fax.: $\quad+61242213725$

E-mail: ass02@uow.edu.au

\begin{abstract}
The relationship between budget deficits and macroeconomic variables (such as growth, interest rates, trade deficit, exchange rate, among others) represents one of the most widely debated topics among economists and policy makers in both developed and developing countries. However, the purpose of this paper is to examine the extensive literature to such a relationship, concentrating on theoretical debates, empirical studies, and econometric models in order to derive substantive conclusions, which can be beneficial in terms of macroeconomics area or in terms of constructing or developing a macroeconomic model for analysing the impact of budget deficits on macroeconomic variables. The majority of these studies regress a macroeconomic variable on the deficit variable. These studies are cross-country and utilise time series data. In general the key outcomes from the studies presented in this paper indicated that both the method of financing and the components of government expenditures could have different effects. Therefore, it is crucial to distinguish between current and capital expenditure when evaluating the impact of fiscal policy on private investment and output growth. Even though, the overall results from the empirical literature with respect to the impact of public investment on private investment and growth are ambiguous, the bulk of the empirical studies finds a significantly negative effect of public consumption expenditure on growth, while the effects of public investment expenditure are found to be positive although less robust. The key outcome from all of the studies presented in this paper which investigating the relationship between the budget deficit and current account deficit showed strong evidence in both developed and developing countries towards supporting the Keynesian proposition (conventional view) which suggests that an increase in the budget deficit would induce domestic absorption and, hence import expansion, causing a current account deficit. Furthermore, it can also be concluded from the empirical findings that the effects of budget deficits on exchange rates depends on the way of funding the deficits, whether through taxation or through money growth. The key findings from the empirical studies investigating the relationship between the budget deficit and interest rates indicated strong evidence towards supporting the Keynesian model of a significant and positive relationship between budget deficits and interest rates. The major outcomes from the empirical studies examining the relationship between budget deficits and inflation showed strong evidence that the budget deficit financed through monetisation and a rising money supply could lead to inflation.
\end{abstract}

\footnotetext{
* I would like to thank A/P Charles Harvie and A/P Edgar J Wilson for their helpful comments and suggestions.
} 


\section{Introduction}

Chronic government budget deficits and escalating government debt have become major concerns in both developed and developing countries. An extensive theoretical and empirical literature has been developed to examine the relationship between the budget deficit and macroeconomic variables. At a theoretical level, much of the literature [e.g. Bailey (1971); Buiter (1977); D avid and Scadding (1974); Premchand (1984); Y ellen (1989); Barro (1990); among others] has focused on the relationship between private investment and public expenditure mainly because of the crowding out effect of public spending. Some of these studies, such as Premchand (1984), assert that financing the budget deficit by borrowing from the public implies an increase in the supply of government bonds. In order to improve the attractiveness of these bonds the government offers them at a lower price, which leads to higher interest rates. The increase in interest rates discourages the issue of private bonds, private investment, and private spending. In turn, this contributes to the financial crowding out of the private sector. While other literature [e.g. Aschauer, (1989); Eisner (1989); Heng (1997); among others] has argued that higher public investment may raise the marginal productivity of private capital and, thereby, "crowd-in" private investment. Some of these studies, such as Achauer (1989), argue that public capital, particularly infrastructure capital such as highways, water systems, sewers, and airports, is likely to bear a complementary relationship with private capital. Hence, according to Aschauer (1989) higher public investment may raise the marginal productivity of private capital, and, thereby, "crowd in" private investment.

Furthermore, other literature with respect to the impact of budget deficits on macroeconomic variables focuses on the relationship between budget deficits and inflation. Theoretically, an extensive literature [e.g. Metzler (1951); Patinkin (1965); Friedman (1968); Sargent and Wallace (1981); Dywer (1982); Miller (1983); among others] has argued that government deficit spending is a primary cause of inflation. Some of these studies, such as Sargent and Wallace (1981), have supported the proposition that the Central Bank will be obliged to monetise the deficit either now or in later periods. Such monetisation results in an increase in the money supply and the rate of inflation, at least in the long-run period.

In addition, other studies focus on the relationship between the budget deficit and the trade deficit (twin-deficits relationship). The twin deficit hypothesis asserts that an increase in the budget deficit will cause a similar increase in the current account deficit. Theoretical examinations of this issue have resulted in many contrary views. An extensive literature [e.g. Fleming (1962); Mundell (1963); Volcker (1987); Kearney and Monadjemi (1990); Smyth et al. (1995); among others] has argued that government deficits may cause trade deficits through different channels. For example, in a Mundell-Fleming framework, it is argued that an increase in the budget deficit would induce upward pressure on interest rates, causing capital inflows and an appreciation of the exchange rate that will increase the current account deficit. The Keynesian absorption theory suggests that an increase in the budget deficit would induce domestic absorption and thus, import expansion, causing a current account deficit. Another contrary view is provided by Barro (1989), known as the Ricardian Equivalence Hypothesis (REH). He states that shifts between taxes and budget deficits do not matter for the real interest rate, the quantity of investment, or the current account balance. In other words, theoretically, REH negates any relationship between the two deficits.

Moreover, other literature [e.g. Allen (1977); Penati (1983); Bisignano and Hoover (1982); Branson (1985); Hakkio (1996); Stoker (1999); among others] has concentrated on the relationship between the budget deficit and the exchange rate. Some of these studies, such as Bisignano and Hoover (1982), argue that deficits may appreciate or depreciate the exchange rate, depending on the relative importance of wealth effects and relative asset substitution effects. 
Extensive literature [e.g. Feldstein (1982); Dwyer (1982); Mascaro and Meltzer (1983); Plosser (1982; 1987); Kormendi (1983); Aschauer (1985); Evans (1985; 1987); Zahid (1988); Monadjemi (1989); Allen (1990); Cebula (1988; 1991); Al-Saji (1993); Knot and de Haan (1999); Vamvoukas (2000); among others] has focused on the relationship between budget deficits and interest rates. Some of these studies, such as Feldstein (1982); Mascaro and Meltzer (1983); Monadjemi (1989); Cebula (1988); Al-Saji (1993) among others, have used the IS-LM model to study the impact of a budget deficit on interest rates. In contrast others such as Cebula (1988); Cebula and Rhodd (1993); Modeste (2000); among others used the loanable funds model. However, in the economic literature there are two conflicting views regarding the effect of government budget deficits on interest rates. The first view represents the standard analysis where the impact of increased deficits on interest rates operates through the effect of higher spending and increased wealth on the demand for money (e.g. Neoclassical and Keynesian models), while the other view (e.g. Ricardian model) argues that the value of the new debt is simply perceived as the present value of the future tax liabilities. This means that the government debt is not viewed as net wealth, and, as a result, money demand would not be affected. Consequently, interest rates remain unchanged as well. Finally, it is worth noting here that other researchers [e.g. Eisner and Pirper (1987); Nelson and Singh (1994); Karras (1994); Al-Khedair (1996); among many others] have focused on the relationship between the budget deficit and the growth of GDP.

The main purpose of this study is to conduct an overview, both theoretical and empirical, of the relationship between budget deficits and macroeconomic variables (such as growth, interest rates, trade deficit, exchange rate, among others) in order to derive substantive conclusions to such a relationship in which can be used to construct or develop a macroeconomic model for analysing the impact of the budget deficit on macroeconomic variables. The paper is divided into five sections. Section 2 identifies the theoretical debate between budget deficits and macroeconomic variables. It will cover topics such as the crowding in and crowding out effects of public investment; deficits, wealth and spending effects; deficits and the exchange rate; deficits and inflation; and fiscal imbalances and trade deficits. Section 3 will review some of the previous empirical studies with respect to the impact of budget deficits on a host of macroeconomic variables. It will cover the same topics but look at the nature and significance of these relationships from an empirical perspective. Some of the most substantive and important empirical studies will be identified in this section. Section 4 will review some econometric models (such as budget deficit and interest rate models, the IS-LM model, the budget deficit and trade deficit models, the budget deficit and economic growth model, and the budget deficit and multivariable model), which have been used in some empirical studies to investigate the impact of a budget deficit on some macroeconomic variables. Section 5 summarizes some of the most substantive conclusions from the studies presented and the major conclusions derivable from this paper.

\section{Budget Deficit and Macroeconomic Variables: Theoretical Debates}

The purpose of this section is to review some of the major theoretical arguments regarding the linkage between a budget deficit and macroeconomic variables.

\subsection{Budget Deficits, Crowding in and Crowding out Effects Schools of Thought}

After analysing the literature on the effects of budget deficits on private investment one finds three distinct schools of thought, these are Neoclassical, Keynesian, and Ricardian equivalence. Each providing different paradigms. Bernhein (1989) provides a brief summary of the three paradigms. The Neoclassical school considers individuals 
planning their consumption over their entire life cycle. By shifting taxes to future generations, budget deficits increase current consumption. By assuming full employment of resources the Neoclassical school argues that increased consumption implies a decrease in saving. Interest rates must rise to bring equilibrium in the capital markets. Higher interest rates, in turn, result in a decline in private investment ${ }^{1}$.

In addition, there are Keynesians who provide a counter argument to the crowd-in effect by making reference to the expansionary effects of budget deficits. They argue that usually budget deficits result in an increase in domestic production, which makes private investors more optimistic about the future course of the economy resulting in them investing more. This is known as the "crowding-in" effect. It is worth noting here that the traditional Keynesian view differs from the standard Neoclassical paradigm in two fundamental ways. First, it permits the possibility that some economic resources are unemployed. Second, it presupposes the existence of a large number of liquidityconstrained individuals. The second assumption guarantees that aggregate consumption is very sensitive to changes in disposable income.

Many traditional Keynesians argue that deficits need not crowd out private investment. Eisner $(1989$, p. 83) is an example of this group, who suggests that increased aggregate demand enhances the profitability of private investments and leads to a higher level of investment at any given rate of interest. Hence, deficits may stimulate aggregate saving and investment, despite the fact that they raise interest rates. He concludes that "The evidence is thus that deficits have not crowded-out investment. There has rather been crowding in".

It is worth noting that it is argued that public capital crowds out or crowds in private capital, depending on the relative strength of two opposing forces: (1) as a substitute in production for private capital, public capital tends to crowd out private capital; and (2) by raising the return to private capital, public capital tends to crowd in private capital. Therefore, on balance, public capital will crowd out or crowd in private capital, depending on whether public and private capital are gross substitutes or gross complements (see, for example, Aschauer (1989b)). Furthermore, Aschauer (1989a, 1989b) argues, on the one hand, that higher public investment raises the national rate of capital accumulation above the level chosen (in a presumed rational fashion) by private sector agents; therefore, public capital spending may crowd out private expenditures on capital goods on an ex ante basis as individuals seek to re-establish an optimal intertemporal allocation of resources. On the other hand, public capital, particularly infrastructure capital such as highways, water systems, sewers, and airports, is likely to bear a complementary relationship with private capital. Hence, higher public investment may raise the marginal productivity of private capital and, thereby, "crowd-in" private investment.

Finally, there is the Ricardian equivalence approach advanced by Barro (1989) who argues that an increase in budget deficits, say due to an increase in government spending, must be paid for either now or later, with the total present value of receipts fixed by the total present value of spending. Thus, a cut in today's taxes must be matched by an increase in future taxes, leaving interest rates, and thus private investment, unchanged ${ }^{2}$.

Macroeconomists [e.g. Bailey (1971); Buiter (1977); David and Scadding; among others] are interested in the relationship between private investment and public expenditures mainly because of the crowding out effect of public spending. The "crowding-out" effect reduces the ability of the government to influence economic activity through fiscal measures. Furthermore, Yellen (1989) argues that in standard Neoclassical

\footnotetext{
${ }^{1}$ It should be mentioned that the Neoclassical Economist also believes in the crowding-out effect of budget deficits.

${ }^{2}$ For key theoretical objections to the Ricardian Equivalence approach, see Bernhein (1989).
} 
macroeconomic models, the method selected by the government to finance its spending program affects the levels of consumption, investment and net exports. Such models assume that aggregate consumption is higher, and national (private plus public) saving lower, if a given government-spending program is financed by issuing bonds rather than through current taxation. If resources are fully employed, so that output is fixed, higher current consumption implies an equal and offsetting reduction in other forms of spending. Thus, investment and/ or net exports must be fully "crowded out". It is worth noting that it is important to distinguish between "financial" crowding out which has been mentioned before and "resource" crowding out which occurs when the government competes with the private sector on purchasing certain resources (skilled labour, raw materials and so on). When the government sector expands the private sector will contract because of the increase in prices on these resources due to an excess demand by the government, hence this leads to a fall in investment and consumption by the private sector. Thus the government sector's expansion crowds out the private sector. It is worth noting here as well that resource crowding out is an important issue to take into account especially in developing countries where resources are scarce even sometimes to the private sector, so any excess demand for these resources by the government will severely impinge private sector productivity.

Furthermore, Premchand (1984) asserts that financing the budget deficit by borrowing from the public implies an increase in the supply of government bonds. In order to improve the attractiveness of these bonds the government offers them at a lower price, which leads to higher interest rates. The increase in interest rates discourages the issue of private bonds, private investment, and private spending. In tum, this contributes to the financial crowding out of the private sector.

In addition, Barro (1990; 1991) utilised endogenous-growth models by extending them to include tax-financed government services that affect production and utility. $\mathrm{He}$ studied the effects of tax financed government expenditure on investment and output in a cross-sectional study of 98 countries over the period 1960-85. He found that the ratio of real government consumption expenditure to real GDP $\left(g^{c} / y\right)$ had a negative association with growth and investment. The argument was that government consumption had no direct effect on private productivity, but lowered saving and growth through the distorting effects from taxation or government-expenditures programs. It is worth noting that the author measured the ratio of real public gross investment to real GDP $\left(g^{i} / y\right)$. This public investment corresponds to a stock of public capital, $k^{g}$, which generates a flow of services that he views as comparable to the productive services $g$. Hence, this empirical measure identifies $g$ with "infrastructure services", such as transportation, water, electric power, and so on (although hospitals and schools are also components of public capital). In addition, the identification of the flow of services from public capital with productive government services is imperfect. It is worth mentioning that the assumptions in this study are that $\mathrm{g} / \mathrm{y}$ is constant over time for a single country, and that public and private capital have the same depreciation rates. According to the theory the relationship of the growth rate $\gamma$ to $g^{i} / i$ depends on how the government behaves. If governments optimise (go close to the point of maximal growth), $\gamma$ and $g^{i} / i$ would indicate little cross-sectional correlation. On the other hand the association would be positive (or negative) if governments typically choose too little (or too much) productive public services. Thus, this study, by dividing taxfinanced government expenditure into spending on unproductive services (e.g., consumption, subsidizing food) and spending on productive services (e.g., building infrastructure), found that the spending on consumption services affects growth negatively, while spending on productive services affects growth positively. The distinction between 
productive and unproductive government services provides vital information for an analysis of the effects of the government budget on capital formation and growth.

Heng (1997) utilised an overlapping-generations (OLG) model to provide a theoretical framework to analyse the "crowding in" issue of private capital by public capital. The author shows that public capital crowds in private capital through two channels, namely, via its impact on the marginal productivity of labour and savings, and via (gross) complementarity/ substitutability between public and private capital. Kelly (1997) argues that public investment and social expenditures may promote economic expansion by reducing social conflict and, hence, creating a climate conductive for investment in human and physical capital. He also contends that social expenditures enhance growth by fostering welfare and productivity improvements. Kelly (1997) continues to argue that the complementarity of public and private action is likely to be important in developing nations where such factors as severe income disparity, asset concentration, the disparate nature of production in the agricultural and industrial sectors, and fragmented financial markets which characterise most developing countries, may warrant substantial public investment programs. In such instances, public investment is likely to be a central determinant of successful private sector activity and economic growth (e.g. infrastructure capital; social expenditures). The complementary hypothesis is crucial because it implies that public investment has direct and indirect influences on economic growth. These indirect effects may be channelled through private investment and national output. Public investment may directly raise growth by adding to the stock of total social capital. Public investment may indirectly enhance growth by improving the climate for private investment through public good provision. Furthermore, public investment may increase current national output, which in turn stimulates higher private investment and higher growth. The author also departs from conventional approaches by emphasising that public investment programs may assist nations channel saving (and borrowing) to productive use. While even the crowding-out literature has recognised that a limited amount of public investment may contribute to growth, that literature has tended to view social programmes, with the exception of education, as unproductive. Hence, the literature recently has largely ignored the effects of social expenditures other than education on economic growth (Kelly, 1997).

Hence, it can be concluded from the above discussion that at the theoretical level it is necessary to take into account, when we are analysing the effects of fiscal policy, both the demand and the supply sides of the economy. However, as mentioned earlier, public investment is likely to be a central determinant of successful private sector activity and economic growth (e.g. infrastructure capital; social expenditures). Therefore, higher public investment may raise the marginal productivity of private capital and, thereby, "crowd-in" private investment (Aschauer, 1989).

\subsection{Deficits, Wealth and Spending Effects}

There are many ways in which a government's choice of fiscal instruments may influence the country's net wealth (and the current account balance as part of changes in that net wealth). The most obvious way in which governments can use fiscal measures to affect net wealth and the current account balance is by their own expenditure (this will be discussed later in this section).

Barth et al. (1986) suggests that, as long as the rate of growth of output $(\dot{y})$ exceeds the rate of interest $(i)$, public debt is unambiguously net wealth. The reason is that, in such circumstances, future taxes are not necessary to service the debt. Economic growth will accommodate indefinite deficits without jeopardizing the tax raising capacity of the economy. If $\dot{y}$ is less than $i$, then the status of national debt is ambiguous. Government debt will be considered "net wealth only to the extent that current generations do not fully discount the increase in future tax liability to service the debt, which in this case cannot be 
serviced solely with revenues generated by economic growth" (Barth et al., 1986, p. 28). If $i$ exceeds $\dot{y}$, and there is no primary surplus (revenues less outlays net of interest payments), then federal debt will grow more rapidly than the economy (Abizadeh and Yousefi, 1996).

In addition, Aschauer (1985) argues that government spending of various sorts may affect employment, output, consumption, and investment by altering the wealth or by directly affecting the marginal productivity of labour and private capital. He also pointed out that the negative wealth effect associated with the temporary rise in government purchases induces the agent to decrease consumption and increase labour supply.

Barro (1989) argues that the Ricardian results depend on "full employment", and surely do not hold in Keynesian models. In standard Keynesian analysis, if everyone thinks that a budget deficit makes them wealthier the resulting expansion of aggregate demand raises output and employment and thereby actually makes people wealthier. This result holds if the economy begins in a state of "involuntary unemployment". There may even be multiple, rational expectations equilibria, where the change in actual wealth coincides with the change in perceived wealth. This result does not mean that budget deficits increase aggregate demand and wealth in Keynesian models. Barro (1989) argues that if we had conjectured that budget deficits made people feel poorer, the resulting contractions in output and employment would have made them poorer. Similarly, if we had started with the Ricardian notion that budget deficits did not affect wealth, the Keynesian results would have verified that conjecture. The odd feature of the standard Keynesian model is that anything that makes people feel wealthier actually makes them wealthier (although the perception and actuality need not correspond quantitatively). This observation raises doubts about the formulation of Keynesian models, but says little about the effects of budget deficits (Barro, 1989, pp. 47-48).

Ball and Mankiw (1995) argue that in the long run an economy's output is determined by its productive capacity, which in turn is partly determined by its stock of capital. When deficits reduce investment the capital stock grows more slowly than it otherwise would. Over a year, or two, this crowding out of investment has a negligible effect on the capital stock. But if deficits continue for a decade or more, they can substantially reduce the economy's capacity to produce goods and services. Moreover, recall that budget deficits, by reducing national saving, must reduce either investment or net exports. As a result, they must lead to some combination of a smaller capital stock and greater foreign ownership of domestic assets. If budget deficits crowd out capital, national income falls because less is produced; if budget deficits lead to trade deficits, just as much is produced, but less of the income from production accrues to domestic residents (Ball and Mankiw, 1995).

In addition to affecting total income, Ball and Mankiw (1995) argue that deficits also alter factor prices: wages (the return to labour) and profits (the return to the owners of capital). According to the standard theory of factor markets the marginal product of labour determines the real wage, and the marginal product of capital determines real profits. When deficits reduce the capital stock the marginal product of labour falls, for each worker has less capital to work with. At the same time the marginal product of capital rises, for the scarcity of capital makes the marginal unit of capital more valuable. Therefore, to the extent that budget deficits reduce the capital stock, they lead to lower real wages and higher rates of profit. Hence, according to Ball and Mankiw the accumulated effects of the deficits alter the economy's output and wealth

Perkins (1997) argues that if a government attempts to improve the current account balance by reducing its own spending on useful infrastructure, the consequent decline in net wealth is likely to exceed whatever benefit arises from the stronger current account. If the government reduces its expenditure overseas-on such items as defence or diplomatic 
activity - that will tend to strengthen the current account (and to that extent increase national net wealth) without reducing its outlays within the country, so that there is no general presumption that this form of reduction in government outlays will reduce the level of activity or domestic real investment.

In general, government spending on productive capital (including human capital) in large and highly industrialized countries, probably has a relatively low import content (apart from those forms of capital investment associated with overseas military spending). A reduction in the general level of government spending on goods and services will often tend to reduce domestic activity more than imports (the UK is probably an example of such a country). On the other hand, for countries that have to import much of their capital equipment, a rise in government outlays on infrastructure may well be expected to lead to a larger current account deficit at any given level of activity (Australia is an example of such a country). It is, moreover, possible that the strengthening of the country's exchange rate consequent on the reduction in the government's claims for foreign exchange, will have adverse effects on the profitability of domestic industry. This may reduce output below capacity and have adverse consequences for the country in terms of both its level of employment and real output, and also of its net wealth (Perkins, 1997, pp. 82-83). Furthermore, Perkins points out that the effects on the current account, or national net wealth, from different fiscal measures to stimulate investment are likely to vary greatly with the extent to which a country produces its own investment goods. This is likely to be a much more important consideration than whether the stimulus to investment is brought about by higher government infrastructure spending or by an increase in tax concessions to private investment.

D evereux and Love (1995) investigated the impact of government spending policies in a two-sector endogenous growth model developed by King and Rebelo (1990) and Rebelo (1991), extended to allow for an endogenous consumption leisure decision. Devereux and Love (1995) concluded that there is a positive relationship between lump sum financed government spending and growth rates. The explanation of this, as in many "endogenous growth" models, is that the rate of growth is positively related to the rate of return on human and physical capital accumulation. The return on human capital accumulation is higher the greater is the fraction of time spent working, in either sector. A higher rate of government spending generates negative wealth effects (as in Aiyagari, Christiano, and Eichenbaum, 1992), leading to a reduction in leisure and a rise in hours worked. Consequently, the rate of growth rises. Although government spending raises the long-run growth rate; it reduces welfare since government spending is a less than perfect substitute for private spending (were they perfect substitutes, the growth rate would be unaffected) (D evereux and Love, 1995).

Moreover, when government spending is financed with an income tax, or by a wage tax, the negative wealth effect of the rise in spending on labour supply conflicts with a substitution effect, which leads to a reduction in labour supply. In this case the spending increase always reduces the growth rate. In this literature on the output effects of government spending, a temporary spending policy has only temporary effects on the level of output (D evereux and Love, 1995).

\subsection{Deficits and the Exchange Rate Debate}

An extensive literature has examined the relationship between the budget deficit and exchange rates. Abstracting from direct spending effects, or transactions crowding-out, a central concern of large budget deficits can be stated as the "portfolio Crowding-O ut" hypothesis. This hypothesis asserts that debt disturbances, associated with large deficits, 
will adversely affect key asset prices, which will induce reductions in aggregate demand ${ }^{3}$. In a closed economy this hypothesis implies a significant positive association between debt stock disturbances (budget deficits) and real interest rates. Such a relationship is consistent with a domestic loanable funds ${ }^{4}$ approach to interest rate determination.

In an open economy, portfolio crowding-out can arise through the exchange rate affecting the current account. This view stresses the importance of international capital movements in response to debt disturbances and the linkage between budget deficits and exchange rates (Bundt and Solocha, 1988). An example of "exchange rate crowding-out" is found in Mundell (1963) and Fleming (1962), who showed that, in a small open economy model with fixed prices and static exchange rate expectations, expansionary debt-financed fiscal policy is completely crowded out under a flexible exchange rate and perfect capital mobility. Dissatisfaction with the flow approach to modelling exchange rates gave rise to the portfolio-balance approach and monetary approaches ${ }^{5}$. The portfolio-balance approach follows Floyd (1969), who argued that analysis of international capital movements should be formulated in the context of a stock portfolio adjustment model. The class of portfoliobalance exchange rate models (Girton and Henderson, 1976; Branson, Halttunen, and Masson, 1977; Marston (1980)) follow Tobin (1969) in concentrating on short-run impact effects of changes in outside asset stocks on asset prices. These models view the exchange rate as an asset price where exchange rate expectations play an important role in explaining exchange rate variability . $^{6}$

While the literature on the linkage between deficits and exchange rates is small compared to the literature on deficits and interest rates, some notable studies have been undertaken by Allen (1977) who looks at stability surrounding the deficit in a small, openeconomy dynamic portfolio balance model. Using a small-country setting with static exchange rate expectations, Bisignano and Hoover (1982) show how increases in the deficit may appreciate or depreciate the exchange rate depending on the relative importance of wealth effects and relative asset substitution effects ${ }^{7}$. They conclude that the deficit, combined with tight monetary policy, will cause the currency to appreciate. Furthermore, Barro (1974) argued that, if it is assumed that taxpayers realize that current deficits must be

\footnotetext{
${ }^{3}$ For a closed economy discussion of portfolio crowding-out and how it relates to other forms of crowding-out, see Friedman (1978).

${ }^{4}$ According to the LFT (Loanable Funds Theory) interest rates are determined as a result of interaction
between supply and demand for loanable funds. Supply of loanable funds includes national saving and
changes to the stock of money. Demand for loanable funds is composed of investments and changes in
demand for money balances. An increase in supply or a reduction in demand for funds reduces interest
rates. On the other hand, a decline in supply or an increase in demand for funds causes higher interest
rates (Hoelscher, 1983; 1986).
}

${ }^{5}$ See Kouri (1976) for a rigorous exposition on the shortcomings of the flow approach to exchange rate determination.

${ }^{6}$ See Mussa (1976) for a good discussion of the implications of viewing the exchange rate as an asset price, as well as the role of exchange rate expectations in explaining exchange rate volatility.

7 The relationship between an increase in the domestic country debt stock and the domestic country currency depends on relative substitutability in wealth between domestic money, domestic bonds, and foreign bonds. Intuitively, an increase in the domestic debt stock may produce either excess demand or excess supply of foreign bonds, which may require either a depreciation or an appreciation of the domestic currency to re-equilibrate this market. Here, the exchange rate serves to revalue domestic wealth to bring the demand for foreign assets into line with the supply. See Branson, Halttunen, and Masson (1977), Bisignano and Hoover (1982), and Penati (1983) for a more detailed analysis of this relationship. 
paid by future taxes, they will increase their savings by an amount equal to the present value of future tax liabilities due to current deficits. Therefore, government deficit financing offset by higher saving does not affect interest rates or the exchange rate (Barro, 1989).

An outgrowth of the monetary approach to exchange rate determination, the currency substitution hypothesis, argues, that the world portfolio demand for currencies of developed economies is sensitive to exchange rate expectations. Thus, currency substitution exposes economies to international financial disturbances that reverberate through international money markets. An important lesson of the currency substitution literature is the distinction between currency mobility and capital mobility for issues of monetary control in the open economy. Boyer (1978) has shown that currency mobility, as distinct from capital mobility, is an important mechanism of international portfolio adjustment. McKinnon (1982; 1984) and Cuddington (1983) have shown that currency substitution will hamper independent monetary control under flexible exchange rates. Similarly, Swanson and How (1986) argue that efficient international cash management policies may enhance spot currency market volatility. Daniel (1985), using a two-country perfect foresight model, shows how currency substitution acts as a channel for the international transmission of monetary disturbances under flexible exchange rates. The implication is that monetary effects of fiscal policy are transmitted through international money markets, which, outside of international policy coordination, influence the exchange rate and alter the choice set of policymakers concerning monetary control. Thus, portfolio models that ignore currency substitution restrict portfolio behaviour and therefore neglect an important channel by which asset prices are determined (Bundt and Solocha, 1988).

In addition to the flow approach to modelling exchange rates, portfolio balance, monetary approach, and currency substitution approaches have, as noted earlier, been developed by many researchers. Authors like Allen (1977), Penati (1983), Branson (1985), Bisignano and Hoover (1982), Hutchison and Pigott (1984), Hutchison and Throop (1985), Evans (1986), Frenkel and Razin (1987), Bundt and Solocha (1988), Abell (1990), and Hakkio (1996) have utilised alternative and complementary models of exchange rates to investigate whether a budget deficit leads to a currency appreciation or vice versa. Here, we limit our discussion to some recent developments. Hakkio (1996) theoretically (empirical work relating to this study will be presented in section 4.3) provides a summary of the direct and indirect effects of deficits on exchange rates. He analysed the direct impact of a deficit reduction within the framework of the crowding-out effect. Lower deficit financing by government reduces the demand for loanable funds, which lowers interest rates and makes foreign portfolio assets more attractive. D emand for foreign currency rises, and, as a result, the domestic currency depreciates. In addition, Hakkio (1996) argues that the indirect effects of budget deficits are mainly related to the role of expectations in asset allocation. Market expectations of future deficits and exchange rates lead to immediate change in exchange rates and higher volatility in the market.

Hakkio provides a summary of the indirect effects of a deficit on the exchange rate. He argues that a deficit reduction can cause a higher demand for loanable funds through three major channels: lower expected inflation, lower foreign exchange risk, and a greater expected rate of return on domestic assets because of lower inflation. Large-size or out of control budget deficits that are financed by printing money lead to higher inflationary expectations (Hakkio, 1996). Even if the debt is not monetised, its large size could convince the markets that it eventually will be paid through an inflation tax. A credible attempt to control the deficit lowers inflationary expectations and the inflation premium on long-term interest rates. Based on the Fisher effect, nominal long-term interest rates could decline by the same percentage and real rates would remain the same. However, if nominal long-term interest rates do not fall as much as the expected inflation premium has declined, 
then real long-term rates would increase. Thus, a deficit reduction makes domestic assets more attractive and causes the currency to appreciate. Furthermore, the overall effect of a deficit reduction on the exchange rate is dependent on whether the deficit reduction is credible, long-term, and sustainable (Hakkio, 1996).

Stoker $(1999)^{8}$ used a two-country cash-in-advance framework with an explicitly specified government sector. The cash-in advance constraint will hold for both purchases of consumption goods and government debt. This study focuses on the impact of government deficit spending on the exchange rate. Stoker concluded that the level of deficit spending made by a government affects the exchange rate in two ways. In the short term, an increase in deficit spending results in an increase in the value of a country's currency. However, this is not simply due to the deficit - it is caused by the increase in government spending this deficit permits. In the long term, the effects of this deficit hinge on how the debt is to be paid for. If the debt is paid by taxation, it results in a temporary decrease in the value of the currency. If the debt is paid for through money growth, the decline is permanent.

It can be concluded from the discussion presented in this section that the theoretical relationship between budget deficits and the exchange rate is ambiguous. For example, a deficit can lead to a weaker exchange rate. When the government runs a budget deficit, it generally enters financial markets and borrows funds to pay the excess of spending over taxes. If the budget falls, hence the government needs to borrow less, this causes the demand for funds and thus domestic interest rates to decline. As interest rates decline, the exchange rate depreciates. In contrast, a decline in the budget deficit can lead to a stronger exchange rate. Suppose that the budget deficit falls, this leads directly to a decrease in the demand for funds by the government and it may also indirectly lead to an increase in the demand for funds by private investors. The increase in the demand for funds may bring about one of three effects, (1) lower expected inflation, (2) a lower foreign exchange risk premium, and (3) a greater expected rate of return on domestic securities. These indirect effects induce private investors to increase their demand for domestic securities relative to foreign securities. As investors switch from foreign to domestic securities, the exchange rate could tend to appreciate (Hakkio, 1996).

\subsection{Deficits and Inflation Debate}

Government deficits and its financing as a primary cause of inflation has received serious attention since Friedman (1968). Three different connections between budget deficits and inflation are predominant in the literature. The most direct connection between government deficits and inflation is that by increasing the real value of outstanding bonds and perceived net wealth, a deficit can raise total spending and the price level because the economy is operating at full employment (Dwyer, 1982). This connection is also the most long-standing, and is suggested, for example, by Metzler (1951) and Patinkin (1965).

Friedman (1968) argued that the monetary authorities could control the inflation rate, especially in the long run, with control of the money supply. Deficits can lead to inflation, but only to the extent that they are monetised. Thus, money-financed deficits are inflationary; bond-financed deficits need not be ${ }^{9}$. Whether bond-financed deficits are

\footnotetext{
${ }^{8}$ It is worth noting that three assumptions made in Stoker's study are important to emphasise. Firstly, goods from different countries enter the agents' utility functions separately in the model, there is no purchasing power parity. Secondly, the government explicitly purchases goods from its own country. Finally, the cash-in-advance constraint holds for both purchases of consumption goods and government debt. For further discussions about the model used in this study and the assumptions, see Stoker (1999).
}

\footnotetext{
${ }^{9}$ Buchman and Wagner (1977) argued that government deficits would be monetised due to political pressure; the monetary authorities do not have a true choice.
} 
inflationary or not depends upon the current approach to policy of the monetary authorities. If they are stabilizing (pegging) interest rates then bond-financed deficits are inflationary, because this calls for an expansion in the money supply that ultimately leads to rising prices. Sargent and Wallace (1981) have supported the proposition that the Central Bank will be obliged to monetise the deficit either now or in later periods. Such monetisation results in an increase in the money supply and the rate of inflation, at least in the long-run period. An alternative view, expounded by Miller (1983), argues that government deficits are necessarily inflationary irrespective of whether the deficits are monetised or not. According to Miller, deficit policy leads to inflation through different channels. The Central Bank might be forced into monetary accommodation of the deficits as argued by Sargent and Wallace (1981). But, even if the Central Bank does not monetise the deficit, deficits are still inflationary through crowding out. That is, non-monetised deficits lead to higher interest rates. Higher interest rates crowd out private investment, and hence reduce the rate of growth of real output. Higher interest rates also spur the financial sector to innovate in the payment system and make government bonds more substitutable for money ${ }^{10}$.

Barro (1978; 1979) has put forward a hypothesis that deficits are a result of inflation, rather than inflation being a result of deficits. The government deficit is the change in the nominal value of outstanding government bonds. If the anticipated inflation increases, then the nominal value of bonds must increase to maintain the real value of outstanding bonds. In addition, the Monetarists have argued that there is a positive link between government deficits and monetary growth, asserting that higher bond-financed deficits will put upward pressure on interest rates and on government bonds. Because the Central Bank is concerned with smoothing interest rate movements, so it would then tend to increase the money supply (D arrat, 1985).

Furthermore, Sargent and Wallace (1981) showed that if the time paths of government spending and taxes are exogenous, bond-financed deficits are nonsustainable because it will push interest rate excessively high and the Central Bank would eventually have to monetise the deficit. This will increase the money supply and inflation in the long run. These findings have subsequently been generalized for the open economy case and for alternative forms of financing (see Scarth 1987; Langdana 1990).

Meltzer (1989) provided a monetarist approach to the budget deficit by arguing that deficits have an effect on inflation. He argued that Argentina, Bolivia, and Brazil provide examples of inflation that was financed by money issued to pay for government spending during the 1980s. Furthermore, he argued that the experience in most developed countries does not support the view that deficits must sooner or later increase money growth and produce inflation. An example is Italy, which experienced a budget deficit of about 10 percent of GNP throughout the 1980s. However, inflation was reduced from about 20 percent to about 5 percent a year during this period. Other examples of persistent deficits and declining inflation are noticeable in Japan and the

\footnotetext{
${ }^{10}$ Miller (1980) argued that current bond-financed deficits do not imply a future tax liability to society. The government will issue more bonds to cover the maturing indebtedness as well as any new addition to total indebtedness. Hence, since government bonds are not backed by tangible assets or by future taxes; the bonds are in essence a part of the money supply. Cox (undated) argued analogously that if interest payments on government bonds are financed by deficits, then government bonds are net nominal wealth. An increase in government debt will therefore result in a higher price level as a result of an increase in the money supply.
} 
United States. In Japan the inflation rate was almost zero while the budget deficit climbed during the 1980s. During the same period the inflation rate in the U.S. declined from 10 percent to about 4 percent, despite the increasing budget deficit of the 1980s (Meltzer, 1989). The reason for the decline in inflation rates can be attributed to the decline of money growth despite borrowing.

Abizadeh et al. (1986) in their studies focus on the link between deficits and inflation. They argue that one way of resolving the controversy over deficits and inflation is "to test the possibility of a causal link between the growth of government expenditures and inflation. This should be done in light of the fact that governments can grow without necessarily generating deficits" (p. 394). The authors' study led them to conclude that "the hypothesis of a direct link between the size of the deficit and the size of government is maintained" (p. 408). An implication was that large deficits are caused by increased government expenditures. If increased government expenditures result in higher deficits, and higher deficits in turn cause inflation, then increased government expenditure can cause inflation.

It can be concluded from the above discussion that the inflationary effect of government deficits depends upon the means by which the deficit is financed, and the impact of the deficit on aggregate demand. If the government attempts to finance budget deficits through bond issues, this could be justified by the notion that the link between budget deficits and inflation (or inflationary expectations) depends on money creation. Hence inflation is seen as being mainly a monetary phenomenon; in other words, expansion of the money supply is considered to be a factor which, in the medium term, determines the rate of price increases. Furthermore, it is worth noting that there is a direct link between government borrowing requirements and money creation, to the extent that such borrowings are financed by the central bank and the commercial banks (in the form of loans to the Treasury or the purchase of government securities). The authorities may, however, attempt to limit the monetary financing of the budget deficit by selling government securities to the non-bank private sector (households, companies, and financial institutions other than banks). In that case there is no effect on the money supply, as assets are transferred from the private sector to the government and vice versa when the money is spent by the authorities. Thus, whatever the method of financing considered, the effect of the budget deficit on monetary growth will depend mainly on the attitude of the monetary authorities (i.e. whether they decide to accommodate the deficit increase, by allowing the money supply to expand, or not). Hence, from the analysis discussed in this section, it can be said that at the theoretical level there is a close link between deficits and monetary growth on the one hand and inflation on the other.

\subsection{Fiscal Imbalances and Trade Deficits: The Twin Deficits}

A positive association between the government budget and trade balance can be shown in the context of a simple Keynesian open-economy model. In an open economy, gross domestic product, $\mathrm{Y}$, is the sum of private consumption expenditures, $\mathrm{C}$, gross private domestic investment expenditures, I, government expenditures, $\mathrm{G}$, and exports, $\mathrm{X}$, over imports, $\mathrm{M}$ :

$$
Y=C+I+G+X-M
$$

Alternatively, Y equals private consumption expenditures, C, savings, S, and taxes, T:

$$
\mathrm{Y}=\mathrm{C}+\mathrm{S}+\mathrm{T}
$$

Substituting (4.2) in (4.1) and rearranging terms yields: 
Equation (3) suggests net exports equal private and public savings. Assuming there is a balanced fiscal budget $(T-G=0)$ and balanced trade $(X-M=0$, that, is, net exports are 0), then (3) suggests that private domestic saving equals private domestic investment. This is necessarily the case in a closed economy where domestic investment is constrained by domestic saving. However, in an open economy, such a relationship may not always exist. An economy with a foreign sector has access to international financial markets. Studies of the twin-deficits relationship generally proceed from one of two theoretical bases. The hypothesis that increases in the government's budget deficit leads to an increase in the trade deficit follows directly from the MundellFleming model (Fleming, 1962; Mundell, 1963). It is worth noting here that the Mundell-Fleming model is an open economy extension of the IS-LM model. As such, it is not fully "rational"; the assumptions made regarding expectations formation are static. In the Mundell-Fleming framework, an increase in the government's budget deficit can generate an accompanying increase in the trade deficit through increased consumer spending. By increasing the disposable incomes and the financial wealth of consumers, the budget deficit encourages an increase in imports. To the extent that increased demand for foreign goods leads to a depreciation in the exchange rate, the effect on net exports is mitigated. However, the larger budget deficit also pushes up the interest rate (in large open economies) because this appreciates the exchange rate, which encourages a net capital inflow and a larger decline in net exports. The size of the effect is an empirical matter (Shojai, 1999, p. 92).

Volcker (1987) argues that budget deficits lead to trade deficits and both hinder economic growth in the long run. Fieleke (1987) provided the theoretical basis for the relationship between the budget deficit and the trade deficit. He argued that "the dominant theory is that an increase in government borrowing in a country will, other things being equal, put upward pressure on interest rates (adjusted for expected inflation) in that country, thereby attracting foreign investment. As foreign investors acquire the country's currency in order to invest there, they bid up the price of that currency in the foreign exchange market. The higher price of the country's currency will discourage foreigners from purchasing its goods but will conversely encourage residents of the country to use their now more valuable currency to purchase foreign goods, so that the country's current account will move toward a deficit (or toward a larger deficit). In addition, any increase in the country's total spending resulting from the enlarged government deficit will go partly for imports and for domestic goods that would otherwise be exported, also worsening the current account balance" (pp. 173-174).

Moreover, the Keynesian absorption theory suggests that an increase in the budget deficit would induce domestic absorption and hence import expansion, causing a current account deficit. Feldstein and Horioka (1980) found that savings and investment are highly correlated, causing budget deficits and current account deficits to move together. An alternative view is that the "twin deficits" are not related in the simple manner depicted by conventional economists. The link from the budget deficit to the current account deficit can be weak or nonexistent. Therefore, there may not exist any predictable or systematic relationship between the two deficits given that there could be many other factors that might serve to make the "twin" relationship doubtful. One such factor concerns the stability of saving and investment over time (Khalid et al., 1999).

Another contrary view is provided by the Ricardian Equivalence Hypothesis (REH) (Barro, 1989). He states that shifts between taxes and budget deficits do not matter for the real interest rate, the quantity of investment, or the current account 
balance. In other words, the REH negates any link between the two deficits, though empirical evidence is mixed (this will be discussed later).

To sum up, as discussed earlier, economic theory suggests that there is a link between the so-called twin deficits in open economies. Increased budget deficits lead to an increase in the interest rate. An increase in the interest rate appreciates the exchange rate. In turn, exports become relatively expensive and imports cheaper, thus generating a trade deficit. Hence, empirical evidence of a relationship between the two would be very important to enable economists and policymakers to better understand whether there is a causal relationship or merely a correlation between these two variables (this will be discussed later).

\section{Empinical Studies}

While the selection of an appropriate paradigm provides us with some clue as to the likely effects of budget deficits, the issue is ultimately an empirical one. Today, there is a vast body of research that examines the relationship between budget deficits and a host of economic variables.

Table $1^{11}$ summarises the results from empirical studies on the relationship between budget deficits and macroeconomic variables in both developed and developing countries. The majority of these studies regress a macroeconomic variable on the deficit variable. These studies are cross-country and utilise time series data. Some of these studies appear to provide considerable evidence in favour of a relationship between the budget deficit and a certain macroeconomic variable.

\subsection{Deficits, Crowding-out and Crowding in Effects of Public Expenditure}

As discussed earlier there are two views on the effects of increased government expenditure on investment. The traditional one argues that government expenditure crowds out private investment. While the non-traditional view sees government expenditure stimulating investment. The crowding in of investment occurs when the economy's resources are un-and underemployed. Much empirical work exists that examines the effect of government expenditure on economic growth. Guess and Koford (1984) used the Granger causality test to find the causal relationship between budget deficits and inflation, GNP, and private investment using annual data for seventeen OECD countries for the period 1949 to 1981 . They concluded that budget deficits do not cause changes in these variables. Furthermore, there are other studies that examine the relationship between government spending and economic growth using crosscountry data in attempts to explain the observed differences in growth rates across countries. For example, Landau (1983), in a cross-sectional study of over 100 countries, reported evidence of a negative relationship between the growth rate of real per capita GDP and the share of government expenditure in GDP. Using data on 47 countries over the 1950-77 period, Kormendi and Meguire (1985) found no significant cross-sectional relationship between the growth rate of real GDP and the growth rate of government consumption spending on output.

Using annual data for the US over the period 1953-1986, Aschauer (1989b) empirically examined the effect of public expenditure on private investment and the rate

\footnotetext{
${ }^{11}$ Some of the empirical studies presented in this section are not included in Table 1 . The studies, which are included in the Table, were chosen because they appear to provide considerable evidence towards a relationship between budget deficits and certain macroeconomic variables in both developed and developing countries.
} 
of return to private capital. He argues that an increase in public investment may be expected to reduce private investment nearly one-to-one as the private sector utilizes the public capital for its required purposes rather than expand private capacity. At a deeper level, a distinctive feature of public infrastructure capital is that it complements private capital in the production and distribution of private goods and services. Hence, public investment might be thought to raise private investment as the former raises the profitability of private capital stock. The empirical results indicate, "that while both channels appear to be operating, the latter comes to dominate, so the net effect of a rise in public investment had a positive effect on private investment"(Aschauer, 1989, p. 186). This means that government investment had a positive effect on private investment and caused "crowding-in" rather than "crowding-out".

Barro (1991) examined 98 countries during the period 1960-1985 and reported a negative relationship between the output growth rate and the share of government consumption expenditures. When the share of public investment was considered; however, Barro (1991) found a positive but statistically insignificant relationship between public investment and the growth rate.

Miller and Russek (1997) consider a sample of developed and developing countries from 1975 to 1984 . They find that both the method of financing and the component of government expenditure can have different effects. Debt-financed increases in defence, health, and social security and welfare expenditures negatively affect the growth of real per capita GDP in developing countries, while debt-financed increases in education expenditure positively affected growth in developed countries. Miller and Russek (1997) differ from prior studies in that they separate the effects of government expenditure based on the method of financing-tax or debt financing.

Argimon et al. (1997) separates private from public investment. Using annual data for fourteen OECD countries for the period 1978 to 1989, they consider the effects, if any, of public consumption and public investment on private investment. They find that public consumption and public investment are negatively associated with private investment although only the public consumption effect is significant.

Kelly (1997) investigated the effects of public expenditure on economic growth among 73 nations (including developing and developed nations) over the period 197089. This study used OLS to estimate economic growth as a function of various public expenditures (such as social expenditure, educational expenditure and other expenditures) and certain variables, which have been prominent in the empirical growth literature such as private investment, and the trade openness variable. This study found that public investment, and particularly housing expenditure, registers a uniformly positive and frequently significant relationship with growth. Although the results do not support a robust relationship between public investment and growth, they nevertheless conflict with the crowding out thesis that dominates the theoretical literature. Social security expenditures are positively related to growth in each specification of the model and significantly so in several versions. The results are important because they suggest that nations may pursue social welfare and growth simultaneously. The results indicate that health expenditures are negatively and sometimes significantly related to growth, while those for education vary in sign and significance.

Ghali (1997) investigated the relationship between government spending and economic growth in Saudi Arabia ${ }^{12}$ using annual data over the period 1960-1996. It

\footnotetext{
12 Saudi Arabia has the largest budget deficit among the Gulf countries. In 1991 the government deficit reached 27 percent of GDP, for a detailed discussion see Ghali (1997).
} 
should be noted here that this study builds on Barro's (1990) endogenous growth model, to untangle the nature of the relationship between these variables ${ }^{13}$. The conclusion of this study "found no consistent evidence that changes in government spending have an impact on per capita real output growth" (Ghali, 1997, p. 171). Ghali and Al-shamsi (1997) utilized cointegration and Granger-causality to investigate the effects of fiscal policy on economic growth for the small oil producing economy of the United Arab Emirates over the period 1973:1-1995:4. They decomposed public spending into consumption and investment expenditures and show how multivariate cointegration techniques can be used to test for the long-run relationships and the intertemporal causal effects between government spending and economic growth. This study provides evidence that government investment has a positive effect on economic growth, whereas the effect of government consumption is insignificant (Ghali and Al-Shamsi, 1997, pp. 530-31).

Monadjemi and Huh (1998) utilised the error correction model (ECM) to examine the relationship between private investment and government spending in Australia, UK, and the US over the period 1970:1-1991:4. Empirical results provide limited support for "crowding out" effects of government investment on private investment. The rate of interest and corporate profitability showed significant effects on private investment in two out of three cases (p. 102). Ghali (1998) used multivariate cointegration techniques to develop a vector error-correction model to investigate the long-run effects of public investment on private capital formation and economic growth. It is worth noting here that this study used a neoclassical production function where the private and public capital stocks are treated as separate inputs. They apply their methodology to data from Tunisia ${ }^{14}$ over the period 1963-93. This study found that in the long run, public investment is found to have a negative impact on growth and private investment. In the short-run, public investment had a negative impact on private investment and no effect on growth.

Bahmani (1999) investigated the long-run relationship between U.S. federal real budget deficits and real fixed investment using quarterly data over the 1947:1-1992:2 period. The methodology in this study is based on the Johansen-Juselius cointegration technique. Their empirical results indicated that real budget deficits have crowded in real investment, supporting the Keynesians who argue for the expansionary effects of budget deficits, by raising the level of domestic economic activity, "crowd- in" private investment (Bahmani, 1999, p. 639).

Ahmed and Miller (2000) examined the effects of disaggregated government expenditure on investment using OLS, fixed-effect, and random-effect methods. This study introduced a government budget constraint; it also distinguished between tax- and debt-financed expenditure. They used pooled time-series, cross-section data (39 countries, 23 developing countries and 16 developed ones) over the period 1975-1984. It is worth noting here that this study ran two sets of regressions. One set uses total government expenditure while the other uses disaggregated expenditure items. The different categories of government expenditure include defence expenditure to GDP, education expenditure to GDP, health expenditure to GDP, social security and welfare

\footnotetext{
13 Saudi Arabia has the largest budget deficit among the Gulf countries. In 1991 the government deficit reached 27 percent of GDP, for a detailed discussion see Ghali (1997).

${ }^{14}$ Which is a developing country that has recently embarked on a large-scale process of privatisation and deregulation of state-own monopolies based on recommendations from the IMF.
} 
expenditure to GDP, economic affairs and service expenditure to GDP, transportation and communication expenditure to GDP, and other expenditure to GDP. This study also included a trade variable, defined as the import plus export share of GDP, because they argue that trade variables (such as the import plus export share of GDP and other measures of openness) explain investment robustly. Their empirical results produce several conclusions. First, the openness variable has a significantly positive effect on investment only for developing countries. For developed countries, openness does not significantly affect investment. Second, expenditure on transportation and communication, crowds in investment for developing countries only. Third, taxfinanced government expenditure, in general, crowds out investment more frequently that debt-financed government expenditure. That finding may suggest the existence of liquidity constraints within the economy. Finally, expenditure on social security and welfare crowds out investment for both tax and debt-financed increases and in both developing and developed countries. This is the only category of government expenditure that had such a consistent (negative) effect across all specifications.

It can be concluded from the empirical studies presented in this section that there are some similarities and differences between these studies dealing with the impact of public investment on private investment and economic growth. The similarities are that some of them focus either on cross-section or static analysis, and used the same estimation technique. For example Barro (1991); Arora and Dua (1993); Nelson and Singh (1994); Kelly (1997); among others estimated their economic model by using the OLS method. Furthermore, many other studies resulted in a similar conclusion in both developed and developing countries and lent support to the existence of a significant crowding-in effect of private investment by public investment, through the positive impact of infrastructure on private investment productivity (e.g. Aschauer (1989b); Kelly (1997); Miller and Russek (1997); Argimon et al. (1997); Ghali and Al-shamsi (1997); Bahmani (1999); Ahmed and Miller (2000); among others).

In contrast other studies suggest different conclusions. Studies such as Landau (1983), Barro (1991), Ghali (1998), among others, found support for a negative relationship between public investment and economic growth. It is worth noting here that one of the important outcomes from these studies indicates that cross-section analysis cannot capture the country specific nature of the government spending and growth relationship. Moreover, time series analysis allows revealing the causal relationship between variables, while cross-section analysis can identify correlation but not causation between variables. It is worth noting as well that, in general, the key outcomes from the studies presented in this section showed that both the method of financing and the components of government expenditure could have different effects. Therefore, it is crucial to distinguish between current and capital expenditure when evaluating the impact of fiscal policy on private investment and output growth. Thus, overall results from the empirical literature with respect to the impact of public investment on private investment and growth are ambiguous, but the bulk of the empirical literature finds a significantly negative effect of public consumption expenditure on growth while the effects of public investment expenditure are found to be positive although less robust. 
Table 1 Selected Empinical Studies of Budget Deficits and Macroeconomic Variables

\begin{tabular}{|c|c|c|c|c|}
\hline Study/ Relationship tested & $\begin{array}{l}\text { Estimation } \\
\text { Period }\end{array}$ & Country & $\begin{array}{l}\text { Methodology/ } \\
\text { Econometric } \\
\text { Technique }\end{array}$ & Major finding \\
\hline \multicolumn{5}{|l|}{$\begin{array}{l}\text { 1-Budget deficit and interest } \\
\text { rates }\end{array}$} \\
\hline Feldstein and Eckstein (1970) & 1954:1-1969:2 & US & IV & -The relatively slow growth of the public debt has exerted downward pressure on interest rates. \\
\hline Hutchison and Pyle (1984) & 1973-1982 & $\begin{array}{l}\text { US-UK- } \\
\text { France- } \\
\text { Japan-Italy- } \\
\text { Canada- } \\
\text { Germany }\end{array}$ & OLS & $\begin{array}{l}\text {-Short-term real interest rates are systematically and positively associated with central government budget } \\
\text { deficits across countries and across time. }\end{array}$ \\
\hline Evans (1985) & $\begin{array}{l}1858-1870 \\
1912-1922 \\
1938-1950 \\
1979-1984\end{array}$ & US & 2SLS & -Large deficits have never been associated with high interest rates. \\
\hline Cebula (1988) & 1955:1-1984:4 & US & IV & -The federal budget deficit exercises a positive and significant impact upon the nominal interest rate. \\
\hline Al-Saji (1993) & 1960:1-1990:2 & UK & 2SLS & $\begin{array}{l}\text {-Government budget deficits do exert a significant and positive effect on nominal and long-term interest } \\
\text { rates. }\end{array}$ \\
\hline Cebula and Rhodd (1993) & 1971-1985 & US & IV & $\begin{array}{l}\text {-Budget deficits (net of debt service payments) exercise a positive and significant impact upon the nominal } \\
\text { long-term rate of interest. }\end{array}$ \\
\hline Liargovas et al. (1997) & 1980-1994 & Greece & $\begin{array}{l}\text { Engle-Granger } \\
\text { Cointegration }\end{array}$ & -There is a positive relationship between government deficits and interest rates in G reece. \\
\hline Vamvoukas (2000) & $\begin{array}{l}1949-1994 \\
1953-1994 \\
1957-1994\end{array}$ & Greece & $\begin{array}{l}\text { Cointegration, } \\
\text { ECM }\end{array}$ & $\begin{array}{l}\text {-Support the Keynesian model of a significant and positive relationship between budget deficits and } \\
\text { interest rates. }\end{array}$ \\
\hline Modeste (2000) & 1964-1996 & Jamaica & $\begin{array}{l}\text { Cointegration, } \\
\text { ECM }\end{array}$ & -Budget deficits force up interest rates and cause "crowding out" of private investment. \\
\hline Cebula (2000) & 1973-1995 & US & IV & -Strong evidence that budget deficits do raise the long-term real ex post rate of interest. \\
\hline \multicolumn{5}{|l|}{$\begin{array}{l}\text { 2-Budget deficit and trade } \\
\text { balance }\end{array}$} \\
\hline Bundt and Solocha (1988) & 1973:II-1987:II & $\begin{array}{l}\text { US-Canada- } \\
\text { Germany }\end{array}$ & SUR & $\begin{array}{l}\text {-There is evidence of a linkage between the budget deficit and the trade deficit arising through the } \\
\text { exchange rate. }\end{array}$ \\
\hline Zietz and Pemberton (1990) & 1972:4-1987:2 & US & 2SLS & $\begin{array}{l}\text {-Budget deficits affect the trade deficit mainly through its impact on domestic absorption and income } \\
\text { rather than through higher interest and exchange rate. }\end{array}$ \\
\hline Abell (1990b) & $\begin{array}{l}\text { 1979:02- } \\
\text { 1985:02 }\end{array}$ & US & VAR & -Budget deficits influence trade deficits indirectly rather than directly. \\
\hline
\end{tabular}


Table 2 Continued

\begin{tabular}{|c|c|c|c|c|}
\hline Study/ Relationship tested & $\begin{array}{l}\text { Estimation } \\
\text { Period }\end{array}$ & Country & $\begin{array}{l}\text { Methodology/ } \\
\text { Econometric } \\
\text { Technique }\end{array}$ & Major finding \\
\hline $\begin{array}{l}\text { Kearney and Monadjemi } \\
(1990)\end{array}$ & 1972:1-1987:4 & $\begin{array}{l}\text { Australia- } \\
\text { UK- } \\
\text { Canada- } \\
\text { France- } \\
\text { G ermany- } \\
\text { Ireland-Italy- } \\
\text { US }\end{array}$ & VAR & $\begin{array}{l}\text {-There is evidence for the existence of a temporary twin deficits relationship that does not persist over } \\
\text { time. }\end{array}$ \\
\hline Bachman (1992) & 1974-1988 & US & VAR & -No evidence of cointegration between the current account and the budget deficit. \\
\hline Islam (1998) & 1973:1-1991:4 & Brazil & $\begin{array}{l}\text { Granger's test of } \\
\text { causality }\end{array}$ & -There is bilateral causality between trade deficits and budget deficits. \\
\hline Piersanti (2000) & 1970-1997 & OECD & $\begin{array}{l}\text { Granger-Sims } \\
\text { causality; IV }\end{array}$ & $\begin{array}{l}\text {-Evidence that strongly supports the view that current account deficits have been associated with large } \\
\text { budget deficits in most industrialised countries. }\end{array}$ \\
\hline \multicolumn{5}{|l|}{$\begin{array}{l}\text { 3-Budget deficit and } \\
\text { inflation }\end{array}$} \\
\hline Darrat (1985) & Post-1960 & US & OLS & -Both monetary growth and federal deficits have had a significant influence on inflation. \\
\hline Ahking and Miller (1985) & $1950-1980$ & US & $\begin{array}{l}\text { Trivariate } \\
\text { autoregressive } \\
\text { model }\end{array}$ & $\begin{array}{l}\text {-For the 1960s, both government deficits and inflation are econometrically exogenous. But for the 1950s } \\
\text { and the 1970s, government deficits, money growth, and inflation are all causally related. }\end{array}$ \\
\hline Metin (1995) & $1950-88$ & Turkey & ECM & -Fiscal expansion dominated the determination of inflation. \\
\hline Metin (1998) & 1950-1987 & Turkey & OLS & $\begin{array}{l}\text {-Budget deficits (as well as real income growth and debt monetisation) significantly affect inflation in } \\
\text { Turkey. }\end{array}$ \\
\hline Darrat (2000) & 1957-1993 & Greece & ECM & $\begin{array}{l}\text {-Besides money growth, higher budget deficits have also played a significant and direct role in the } G \text { reek } \\
\text { inflationary process. }\end{array}$ \\
\hline
\end{tabular}




\begin{tabular}{|c|c|c|c|c|}
\hline Study/ Relationship tested & $\begin{array}{l}\text { Estimation } \\
\text { Period }\end{array}$ & Country & $\begin{array}{l}\text { Methodology/ } \\
\text { Econometric } \\
\text { Technique }\end{array}$ & Major finding \\
\hline \multicolumn{5}{|l|}{$\begin{array}{l}\text { 4-Budget deficit and } \\
\text { exchange rate }\end{array}$} \\
\hline Burney and Akhtar (1992) & 1971-72-1989-90 & Pakistan & OLS & $\begin{array}{l}\text {-Budget deficits have a significant positive impact on the real exchange rate directly as well as indirectly } \\
\text { through the price level. }\end{array}$ \\
\hline Humpage (1992) & 1973-1991 & US & $\begin{array}{l}\text { Engle-G ranger } \\
\text { Cointegration }\end{array}$ & $\begin{array}{l}\text {-No evidence of a long-term relationship between common aggregate interest rates, real dollar exchange } \\
\text { rates, and real net exports. }\end{array}$ \\
\hline Hakkio (1996) & 1979-1994 & OECD & SUR & $\begin{array}{l}\text {-In all countries under investigation, except Japan, UK, and Australia, deficit reduction through cutting } \\
\text { government spending causes the currency to appreciate. }\end{array}$ \\
\hline \multicolumn{5}{|l|}{$\begin{array}{l}\text { 5-Budget deficit/ Public } \\
\text { spending and } \\
\text { growth/ investment }\end{array}$} \\
\hline Aschauer (1989b) & 1953-1986 & US & $\begin{array}{l}\text { Maximum } \\
\text { likelihood }\end{array}$ & -The net effect of a rise in public investment had a positive effect on private investment. \\
\hline Barro (1991) & 1960-1985 & $\begin{array}{l}\text { Cross- } \\
\text { sectional (98) }\end{array}$ & OLS & -A negative relationship between output growth and the share of government consumption expenditures. \\
\hline Arora and Dua (1993) & 1980-1989 & US & OLS & -Higher budget deficits crowd out domestic investment and increase trade deficits. \\
\hline Nelson and Singh (1994) & $\begin{array}{l}1970-1979 \\
1980-1989\end{array}$ & $\begin{array}{l}\text { Cross- } \\
\text { sectional (70) }\end{array}$ & OLS & $\begin{array}{l}\text {-The budget deficit variable exercised little or no impact of any statistical significance on economic growth } \\
\text { in LD Cs during the 1970s and 1980s. }\end{array}$ \\
\hline Kelly (1997) & $1970-1989$ & $\begin{array}{l}\text { Cross- } \\
\text { sectional (73) }\end{array}$ & OLS & $\begin{array}{l}\text { - Public investment (particularly housing expenditure) registers a uniformly positive and frequently } \\
\text { relationship with growth. Although the results do not support a robust relationship between public } \\
\text { investment and growth. }\end{array}$ \\
\hline Argimon et al. (1997) & 1978-1989 & OECD (14) & IV & $\begin{array}{l}\text {-Evidence found that public consumption and public investment are negatively associated with private } \\
\text { investment. }\end{array}$ \\
\hline Ghali and Al-Shamsi (1997) & 1973:1-1995:4 & $\begin{array}{l}\text { United Arab } \\
\text { Emirates }\end{array}$ & $\begin{array}{l}\text { Cointegration- } \\
\text { Granger- } \\
\text { Causality }\end{array}$ & $\begin{array}{l}\text {-Evidence that government investment has a positive effect on economic growth, whereas the effect of } \\
\text { government consumption is insignificant. }\end{array}$ \\
\hline G hali (1997) & 1960-1996 & Saudi Arabia & VAR & $\begin{array}{l}\text {-No consistent evidence found that changes in government spending have an impact on per capita real } \\
\text { output growth. }\end{array}$ \\
\hline G hali (1998) & $1963-93$ & Tunisia & $\begin{array}{l}\text { Granger causality } \\
\text { test, OLS }\end{array}$ & $\begin{array}{l}\text {-Public investment is found to have a negative short-run impact on private investment and a negative long- } \\
\text { run impact on both private investment and economic growth. }\end{array}$ \\
\hline Monadjemi and Huh (1998) & 1960-1991 & $\begin{array}{l}\text { Australia, } \\
\text { UK, US }\end{array}$ & ECM & $\begin{array}{l}\text {-The empirical results provide limited support for "crowding out" effects of government investment on } \\
\text { private investment. }\end{array}$ \\
\hline Ahmed and Miller (2000) & 1975-1984 & $\begin{array}{l}\text { Cross } \\
\text { sectional (39) }\end{array}$ & OLS & $\begin{array}{l}\text {-In general, tax-financed government expenditure crowds out more investment than debt-financed } \\
\text { expenditure. Expenditure on social security and welfare reduces investment in all samples while } \\
\text { expenditure on transport and communication induces private investment in developing countries. }\end{array}$ \\
\hline
\end{tabular}


Table 4.2 Continued

\begin{tabular}{|c|c|c|c|c|}
\hline Study/ Relationship tested & $\begin{array}{l}\text { Estimation } \\
\text { Period }\end{array}$ & Country & $\begin{array}{l}\text { Methodology/ } \\
\text { Econometric } \\
\text { Technique }\end{array}$ & Major finding \\
\hline \multicolumn{5}{|l|}{$\begin{array}{l}\text { 6-Budget deficit and } \\
\text { macroeconomic variables }\end{array}$} \\
\hline D wyer (1982) & $1952-1978$ & US & VAR & $\begin{array}{l}\text {-No evidence is found that larger government deficits increase prices, spending, interest rates, or the } \\
\text { money stock. }\end{array}$ \\
\hline Guess and Koford (1984) & 1949-1981 & OECD (17) & $\begin{array}{l}\text { Granger causality } \\
\text { test }\end{array}$ & -Budget deficits do not cause changes in inflation, GNP, and private investment. \\
\hline Karras (1994) & 1950-1980 & $\begin{array}{l}\text { Cross- } \\
\text { sectional (32) }\end{array}$ & OLS, GLS & $\begin{array}{l}\text {-D eficits do not lead to inflation, deficits are negatively correlated with the rate of growth of real output } \\
\text { and increased deficits appear to retard investment. }\end{array}$ \\
\hline Al-Khedair (1996) & 1964-1993 & G-7 & VAR & $\begin{array}{l}\text {-Budget deficits led to higher short-term interest rates in the seven countries. The budget deficit did not } \\
\text { manifest any impact on the long-term interest rates. The trade balance was worsened by the budget deficit } \\
\text { and economic growth improved in all seven countries. }\end{array}$ \\
\hline
\end{tabular}

Note: In all cross-country studies the number of countries given in parenthesis; OLS=ordinary least squares; IV=instrumental variables; VAR=vector autoregressive model; 2SLS=two stage least squares; SUR=seemingly unrelated regressions; GLS=generalised least squares; ECM=error correction model. 


\subsection{Deficits and Inflation}

As discussed earlier, an extensive theoretical literature [e.g. Metzler (1951); Patinkin (1965); Friedman (1968); Sargent and Wallace (1981): Dywer (1982); Miller (1983); among others] has argued that government deficit spending is a primary cause of inflation. However, the inflationary effect of government deficits depends upon the means by which the deficit is financed and the impact of that on aggregate demand.

Empirical investigations examining the relationship between inflation and budget deficits have not reached a consensus on the possible relationship between the rate of inflation and deficits. The empirical evidence is fraught with contradictory results as well. Dwyer (1982) utilized a vector autoregression model to test the linkage between government deficits and macroeconomic variables (such as prices, spending, interest rates and the money stock) in the U.S. over the period 1952-1978. The results are consistent with the hypothesis that there are no perceived wealth effects of predictable changes in government debt held by the public and, as a result, no effects of the debt on inflation. No evidence is found that larger government deficits increase prices, spending, interest rates, or the money stock.

Crozier (1976) also concluded that there was not a causal relationship between deficits and the Canadian inflationary surge in the 1970s. Hamburger and Zwick (1981) examined the influence of deficits on monetary growth in the U.S. They found that the effect of deficits on the growth of money was operative from 1961 to 1974 and again in 1977 and 1978. Hamburger and Zwick concluded that a combination of an expansionary fiscal policy and the Federal Reserve's attempts at moderating interest rate movements, begun in the mid-1960s, had principally caused a persistent drift toward higher U.S. inflation rates. McMillan and Bread (1982), in their re-examination of Hamburger and Zwick's study, suggested that their results did not support the position that monetary policy is strongly influenced by the U.S. federal government's fiscal policy actions.

Darrat (1985) examined empirically the link between deficits and inflation in the U.S. during the post-1960 period. The estimation results, using the OLS technique, suggested that both monetary growth and federal deficits significantly influenced inflation during the 1960s and 1970s. In addition, he concluded that federal deficits bore a stronger and more reliable relationship to inflation than monetary growth. McCallum (1984) used a perfect foresight version of the competitive equilibrium model to investigate the theoretical validity of a "monetarist hypothesis" - one that asserts "that a constant, per capita budget deficit can be maintained without inflation if it is financed by the issue of bonds rather than money." He found the hypotheses to be valid under a conventional definition but invalid if the deficit is defined to be exclusive of interest payments (Shojai, 1999, p. 69). Ahking and Miller (1985) modelled deficits, money growth, and inflation in the U.S. over the period 1950-1980 as a trivariate autoregressive process. It is also worth noting that their results treated government deficits, base-money growth, and inflation as endogenous variables in the trivariate autoregressive model. This study found that, a two-way causal relationship occurs for the 1950s and the 1970s between government deficits and inflation. Thus, government deficits appear to be inflationary in the 1950s and 1970s but not in the 1960s. Using a rational-expectations macro model of Peruvian inflation, Hafer and Hein (1988) tested the temporal relationship between inflation and privately held federal debt. They found that neither the par value nor the market value of debt were related to inflation (p.239). Eisner (1989) examined the impact of deficits on inflationary pressure to see if structural deficits contribute to inflation. He found that there is no support for the proposition that the federal budget deficit, by any measure, contributes to inflation. If anything the opposite appears to be true (p.87). 
Dua (1993) examined the relationship between long-term interest rates, government spending, and deficits within the context of a rational expectations model. He found that inflation uncertainty and the expected rate of growth of the money supply are important determinants of changes in long-term interest rates. Giffen et al. (1982) argue that the data offers little support for the traditional Keynesian or for the monetarist views on the cause of inflation. They suggest that the investigators might alternatively use some post-Keynesian approach (administered pricing or cost-push analysis) to determine the cause of inflation.

Furthermore, Dornbusch and Fischer (1981), Bhalla (1981), Siddiqui (1989), Choudhary and Parai (1991), Buiter and Patel (1992), Dogas (1992), Sowa (1994), Hondroyiannis and Papapetrou (1994), and Metin (1995; 1998), Darrat (2000), among many others conducted empirical studies of the relationship between the budget deficit and inflation in developing countries. Specifically, Choudhary and Parai (1991) used the rational expectations macro model of inflation to examine the impact of the anticipated budget deficits on inflation rates by using the quarterly data of Peru for the period 1973$: 1$ to $1988: 1$. They found that budget deficits, as well as the growth rate of money supply, have significant impacts on inflation. Similarly, Dogas (1992) found that the public deficit affects inflation in Greece.

Hondroyiannis and Papapetrou (1994) used bivariate cointgrated systems to test the hypothesis of a relationship between the budget deficit and inflation using annual data for Greece for the period 1960-1992. This study employed as a measure of the budget deficit the public sector net borrowing requirement as a percentage of gross domestic product (PSBR), and investigated the direction of causality between the growth of the PSBR and the inflation rate. The major findings of this study suggested that there is a long-run relationship between the PSBR and the price level in the Greek economy. In addition, it observed, using the Granger-causality test, that there is a bidirectional causality between the two variables. The results of the error-correction model suggest that an increase in the public sector net borrowing requirement results in an increase of the inflation rate with a lag of one period.

Using an error-correction model, Sowa (1994) estimated an inflation equation for Ghana over the period 1963-90. This study found that inflation in Ghana is influenced more by output volatility than by monetary factors, both in the long run and in the short run. For Turkey, Metin (1995) analysed the inflationary process in Turkey covering the period of 1950-88, using a general framework of sectoral relationships. It is worth noting here that the government in Turkey shifted from monetisation of the deficit to bond financing in the mid-1980s. The short annual sample on Treasury bonds precluded sorting out the effects of this alternative means of deficit financing. However, this study found that fiscal expansion was a determining factor for inflation. The excess demand for money affected inflation positively, but only in the short run. On the other hand, imported inflation, the excess demand for goods, and the excess demand for assets in the capital markets had little or no effect on inflation. A key policy implication of Metin (1995) is that Turkish inflation could be reduced rapidly by eliminating the budget deficit. Metin (1998) examines the relationship between the public sector deficit and inflation using a parsimonious, conditional, single-equation model for inflation, in which inflation depends on the budget deficit, the real growth rate of income, and base money. He found (using annual data for Turkey over the period 1950-1987) that budget deficits (as well as real income growth and debt monetisation) significantly affect inflation in Turkey $^{15}$. Darrat (2000) utilised an error correction model (ECM) to

\footnotetext{
${ }^{15}$ See Metin (1998) for more details about the economic framework, and the single-equation modelling approach used in this study.
} 
investigate if high budget deficits have any inflationary consequences in Greece over the period 1957-1993. Their empirical results found that the deficit variable exerts a positive and statistically significant impact upon inflation in Greece. They conclude that "besides money growth, higher budget deficits have also played a significant and direct role in the Greek inflationary process" (Darrat, 2000, p. 635).

It can be concluded from the studies reported in this section that there are commonalities and controversies relating to the estimation technique, variables underlying the model specification, and the results. However, overall the empirical evidence on the inflationary effects of deficits is inconclusive. This stems from different theories of deficits and inflation. These studies started from Darrat (1985), Ahking and Miller (1985), Choudhary and Parai (1991), Dogas (1992), Hondroyiannis and Papapetrou (1994), Metin (1998), Darrat (2000), among others, which find that the budget deficit exerted a significant impact on inflation. In contrast, other studies (e.g. Dwyer (1982), Karras (1994), among others) find that deficits do not lead to inflation. But the major outcomes from the empirical studies presented in this section, indicated strong evidence that a budget deficit financed through monetisation and a rising money supply could lead to inflation. However, the inflationary effect of government deficits depends upon the means by which the deficit is financed and the impact of that on aggregate demand.

\subsection{Budget Deficits and Trade Deficits}

Empirical examinations of the twin-deficits relationship have taken many forms, ranging from single-equation ordinary least squares (OLS) models to two-stage least squares models to small-scale structural models to unconstrained vector-autoregression (VAR) models to cointegration and vector-error-correction (VEC) models. Each of these approaches has shortcomings, but some approaches are clearly superior to others. The results obtained are quite sensitive to the modelling technique chosen (Shojai, 1999, pp. 93-94).

As Tallman and Rosensweig (1991, p. 5) note, "Some studies using a MundellFleming framework indicate that the twin deficit notion is consistent with the data. In contrast, other studies, finding no underlying relationship between government and trade deficits, are consistent with the predictions of Ricardian equivalence." Moreover, results also depend upon the data chosen; the choice of variables to include in estimated equations is important, as is the form (levels, first differences, or percentage of gross national product [GNP]) in which variables enter the equations. Furthermore, the form in which variables are entered in equations also appears to be an important determinant of empirical results. Tallman and Rosensweig (1991, p. 7) note that the chances of finding a twin-deficits relationship appear to be greater if variables are entered as levels or as ratios to GNP, rather than as first differences (their empirical results will be presented later).

Early studies of the twin deficits (from the mid-1980s) typically relied on singleequation OLS or two-stage least squares models (e.g. Eisner, 1986; 1991; Summers, 1986). Such studies often found that changes in some measures of the budget deficit are correlated with changes in some measures of the trade deficit. For example, Eisner (1991) estimates an OLS equation using the ratio of net exports to GNP as the dependent variable and including the price-adjusted high-employment deficit as a percentage of GNP as an explanatory variable. He finds, using U.S. data over the period 1957-1988, a positive effect of the budget deficit on the trade deficit, although the 
estimated coefficient is only marginally statistically significant. While Eisner's simple model avoids the non-stationarity problem inherent in using data in levels, its very simplicity - the only other explanatory variable is the change in the real interest rate argues against taking the findings seriously.

Darrat (1988) used Granger causality to test the hypothesis that large budget deficits cause rising trade deficits. He used data from the U.S. covering the period 19601984. Darrat (1988) found that "the empirical results only partially support the conventional view that a rising budget deficit caused the 1980s escalation in the U.S. trade deficit". He continued to say, "I do find evidence of a budget-to-trade deficit causality, but also find, perhaps stronger, evidence of trade-to-budget deficit causality" (Darrat, 1988, p. 886). Zietz and Pemberton (1990) estimate a multi-equation, structural, open economy model of the U.S. economy over the period 1972:4-1987:2. Their model includes equations for short-term interest rates; the real trade-weighted exchange rate; domestic absorption; exports; imports; the domestic inflation rate; and trend absorption. They derive two-stage least squares estimates for each equation. Simulations of the model indicate a strong effect of budget policy on net exports, primarily through the effect of domestic absorption on imports. The effect through rising interest and exchange rates is minor. Despite the sizable effects of fiscal policy on net exports, Zietz and Pemberton concluded that less than half of the trade deficits of the 1980s could be explained by government policy. This study also concluded that the budget deficit affects the trade deficit mainly through its impact on domestic absorption and income rather than through higher interest and exchange rates (Zietz and Pemberton, 1990, p.33).

A number of researchers have estimated VAR models in an attempt to account for the pervasive endogeneity among variables. Abell (1990b) estimated a sevenvariable VAR model using monthly data for the period 1979.02-1985.02, which corresponds to the period of dollar appreciation in the early 1980s. The variables included in the system are the federal government budget deficit, the U.S. merchandise trade balance, the M1 money supply, Moody's AAA bond yield, the Dallas Federal Reserve Bank's 101-country trade-weighted dollar exchange rate, real disposable personal income, and the consumer price index (CPI). In a second paper, Abell (1990a) excluded disposable income and lengthened the sample period to 1977.01-1985.02 but used the same techniques. Abell (1990b) concluded that budget deficits influence trade deficits indirectly rather than directly. He contended, however, that indirect causation running from the budget deficit through the interest rate and the exchange rate to the trade deficit exists. His reported impulse response functions showed a positive response of the trade deficit to a one-standard-deviation shock to the budget deficit. Bachman (1992) tested the twin-deficits hypothesis in the U.S. using quarterly data for the period 1974-1988. He also tested the relationship between the trade deficit and three other "causal variables": gross domestic investment, relative productivity, and the exchange rate risk premium. All of his analysis is bivariate. Finding no evidence of cointegration between the current account and the budget deficit, Bachman estimated bivariate VARs. His results suggested unidirectional Granger causation from the federal deficit to the current account.

Kearney and Monadjemi (1990) utilised the vector autoregressive (VAR) technique to examine international evidence from eight countries (Australia, Britain, Canada, France, Germany, Ireland, Italy, and the United States) using quarterly data over the period of floating exchange rates from 1972:1-1987:4. They estimated five variable VARs for these countries. They did not include the government budget deficit as a separate variable, choosing instead to include government expenditures and tax 
revenues. Their VAR equations include "monetary creation" and the (real, effective) exchange rate but not income or an interest rate. The findings that emerge from their empirical analysis of eight countries can be summarised as indicating the existence of a temporary twin deficits relationship between the stance of fiscal policy and performance on the current account of the balance of payments, which does not persist overtime. Examination of the impulse response functions confirms that fiscal expansions will lead to prolonged periods of improved current account performance as the economy adjusts towards its long run equilibrium. They concluded that the twin deficits relationship varies internationally in magnitude and duration, and it is not independent of the government's financing decision (Kearney and Monadjemi, 1990, p. 216).

Tallman and Rosensweig (1991) investigated the relationship between government deficits and trade deficits in the U.S. over the period 1971-1989. They estimated a four-variable VAR system that includes measures of the real interest rate and the real exchange rate. They found that the government deficit (as a ratio to GNP) Granger causes the trade deficit (as a ratio to GNP) but not vice versa. They reported no variance decompositions or impulse response functions. Their findings reinforce those of Darrat (1988), who examined the existence of Granger causality between the real federal budget deficit and the "real trade deficit" using a system of unconstrained multivariate equations for both the budget deficit and the trade deficit. Enders and Lee (1990) also estimated a VAR system, which they derived from a consumer optimisation model of the economy consistent with the Ricardian Equivalence hypothesis (REH). They estimated a six-variable unconstrained VAR for the post-war period (1974.III1987.I), covering both fixed and flexible exchange rate regimes. Their model contains government expenditures and changes in the federal debt as separate variables. Variance decompositions show a small but significant effect of both government spending shocks and debt shocks on net exports (15.9 percent and 12.9 percent, respectively). Plots of impulse response functions show a sustained decrease in net exports in response to both a government spending shock and a government debt shock. The latter result is, of course, contradictory to the REH. However, when Enders and Lee imposed theoretical restrictions drawn from the Ricardian theory on the model and tested their validity, they were unable to reject Ricardian Equivalence (Shojai, 1999, pp. 97-98). Finally, Volcker (1984), Laney (1986), and Tallman and Rosensweig (1991) find that budget deficits and trade deficits are positively associated. However, in his study of Canada, France, Germany, the United Kingdom and the United States, Evans (1988) maintains that current accounts are unrelated to budget deficits. Feldstein (1992) holds a similar view. Islam (1998) examined empirically the causal relationship between budget deficits and the trade deficits for Brazil from 1973:1 through 1991:4. This relationship is investigated in the context of Granger's test of causality. Empirical results suggested the presence of bilateral causality between trade deficits and budget deficits.

Khalid and Guan (1999) utilised cointegration techniques to examine the causal relationship between budget and current account deficits as well as the direction of such causality. They used a selected sample of five developed countries (US, UK, France, Canada and Australia) and five developing countries (India, Indonesia, Pakistan, Egypt and Mexico) over the period 1950-1994 for developed countries and 1955-1993 for developing countries. It can be noted that the time series variables involved in their studies are the current account deficit, budget deficit, trade-weighted exchange rate and nominal GNP. Their empirical results show that the causal relationship between budget and current account deficits exists in four out of five developing countries, while no developed country exhibits such a relationship. The results suggest that a high correspondence between the two deficits in the long run is more likely to occur in 
developing countries than in developed ones (Khalid and Guan, 1999, p. 399). Egwaikhide (1999) used a macroeconomic model to examine the effects of budget deficits on the trade balance in Nigeria over the period 1973-93 by using the OLS method. Evidence from policy simulations indicate that budget deficits arising from increased government spending adversely affects the balance of trade irrespective of whether it is money-financed or by external borrowing.

Piersanti (2000) utilized the Granger-Sims causality technique to investigate the relationship between the current account deficits and budget deficits for seventeen OECD countries over the period 1970-1997. He used the budget and current account balance as a percentage of GDP, rather than their absolute levels. From the empirical investigation, this study obtained evidence that strongly supported the view that current account deficits have been associated with large budget deficits during the 1970-1997 periods in most industrial countries (Piersanti, 2000, p. 268).

Thus, overall, the empirical evidence on the trade deficit effects of budget deficits is inconclusive. This occurred for many reasons. For example, the methodology used to analyse the above issue varied from well-specified theoretical models to using simple one-to-one relationships between the budget deficit and current account deficit. For instance, studies such as Abell (1990); Tallman and Rosensweig (1991); Khalid and Guan (1999); among others used a simple identity to analyse the linkage between the budget deficit and current account deficit (this identity states that the government budget surplus is equal to the current account surplus plus the excess of investment over private savings). While other studies such as Bundt and Solocha (1988); Egwaikhide (1999); Piersanti (2000); among others used a complicated dynamic macroeconomic model such as standard portfolio models and general equilibrium models. Furthermore, the empirical findings investigating the relationship between budget deficits and trade deficits are ambiguous, as are the theoretical ones in both developed and developing countries. Studies such as Volker (1984), Laney (1986), Bundt and Solocha (1988), Abell (1990b), Kearney and Monadjemi (1990), Arora and Dua (1993), Kasa (1994), Al-Khedair (1996), Islam (1998), Khlalid and Guan (1999), Piersanti (2000), among others found evidence to support the view that there is a significant link between trade deficits and budget deficits mainly through the transmission mechanisms of interest rates and exchange rates. In contrast, other studies which were presented in this chapter such as Evans (1988), Bachman (1992), among others found no evidence for the link between the two deficits. Even though the overall results are inconclusive the majority of these studies have found evidence supporting the twin deficit relationship arising through the exchange rate.

\subsection{Budget Deficit and The Exchange Rate}

It is worth noting here that economic models of exchange rates that incorporate fundamental economic variables such as measures of the money supply, income, and prices have performed poorly compared to random walk models. Many researchers have concluded that there is no significant relationship between exchange rates and fundamental economic variables (Melzer, 1993). In 1983, Meese and Rogoff in a major study, concluded that a random walk model of exchange rates performs as well as any structural model. Other studies have concentrated on the stationarity of real and nominal exchange rates and whether exchange rates and fundamental economic variables are cointegrated (Chinn, 1991). These studies have attempted to establish the existence of a long-run relationship between exchange rates and economic aggregates. Many studies reject that there exists cointegration, suggesting that there is no long-run relationship between these variables. Earlier support of non-stationarity of exchange rates has been 
challenged by many more studies such as Huizinga (1987), Engel and Hamilton (1990), Hakkio and Joines (1990).

Meltzer (1993) provides evidence as to why trade-weighted nominal and real exchange rates move together. This had already been supported by studies done by Mussa (1986) and Edwards (1989) for developed and developing economies. Bundt and Solocha (1988) estimated a general two-country portfolio balance model of exchange rates with currency substitution over the period 1973-1987 for the United States, Canada, and Germany. They found that increases in the U.S. debt stock caused an appreciation of the U.S. dollar against the German mark and the Canadian dollar. This study also presented evidence on the linkage between the budget deficit and the trade deficit arising through the exchange rate.

Moreover, Bohn's (1992) measure of government net worth, which includes principal government assets and liabilities as a measure of the deficit, was utilized, and it was concluded that changes in net worth have no significant effect on the exchange rate. Humpage (1992) utilized the Engle-Granger Cointegration technique to test for the existence of a long-run relationship between the level of the U.S. federal budget deficit and the exchange rate during the period 1973-1991. Unlike many other studies, Humpage used the level of the deficit instead of deficit as a percentage of GDP. He argues that when the level of the deficit is very large, it could have substantially different effects on the exchange rate. This study found no evidence of a long-term relationship between common aggregate measures of U.S. fiscal policy and real longterm interest rates, real dollar exchange rates, and real net exports. Burney and Akhtar (1992) empirically examined the effects of budget deficits on the exchange rate for Pakistan over the period 1971-72 to 1989-90. The estimated results using the OLS method indicate that in the case of Pakistan, government budget deficits have a significant direct impact on the real exchange rate through the price level. Hakkio (1996) used pooled annual data during the period 1979-1994 for eighteen OECD countries and regressed the real exchange rate on the budget deficit as a percentage of GDP. To estimate the indirect impact of a deficit reduction on the exchange rate, a country's inflation rate relative to the average OECD inflation rate, the stock of government debt (as a percentage of GDP) relative to the OECD average, and the change in government spending as a share of GDP are included in the regression line to proxy the impact of expected inflation, risk premium, and the expected rate of return effect on the exchange rate. Hence, the way the government chooses to use these tools (cutting government spending or increasing tax rates) have important effects on the expected rate of return of domestic assets, thereby leading to changes in the demand for domestic assets and in turn to changes in the exchange rate.

The estimated results indicate that the direct impact of a deficit reduction in thirteen countries leads to a stronger currency, but in five countries the currency weakens as the deficit is reduced. Also, in all cases the indirect impacts of deficit reduction have the correct sign and are statistically significant. The overall conclusions indicate that a deficit reduction leads to a stronger currency in the United States, Germany, France, Italy, and Canada. However, deficit reductions through tax increases and spending reductions have different effects on the currency of different countries. In general, in all countries under investigation, except for Japan, the UK, and Australia, cutting the deficits by spending cuts causes the currency to appreciate more than when taxes are increased. In Italy, revenue increases have a small impact on the exchange rate, but spending cuts are more effective. In Portugal and Norway, deficit reduction through tax increases weakens the currency, but spending cuts strengthen the currency (Shojai, 1999, pp. 61-62). 
In conclusion, the theoretical models provide an ambiguous picture of how a deficit reduction affects a currency. The direct impact of such actions can lead to currency depreciation; however, the indirect impacts can overwhelm such exchange rate changes in the opposite direction. Many researchers have estimated the overall impact of fiscal imbalances on the value of a currency. Ironically, the empirical works do not shed any better light on the issue than theoretical models. It seems that depending on the measures of the deficit, the econometric model, and the period of study, different conclusions can be reached.

\subsection{Budget Deficit and Interest Rates}

As discussed earlier in this chapter, in the literature there are two conflicting views regarding the effect of government budget deficits on interest rates. The discussions are centred on the efficacy of the Neoclassical and Keynesian models, on the one hand, and the Ricardian model on the other. The Keynesian models and neoclassical models represent the standard analysis where the impact of increased deficits on interest rates operates through the effects of higher spending and increased wealth on the demand for money. In the Ricardian model, however, the value of the new debt is simply perceived as the present value of the future tax liabilities. This means that the government debt is not viewed as net wealth and, as a result, money demand would not be affected. Consequently, interest rates remain unchanged as well ${ }^{16}$.

Turning to the empirical studies, Dwyer (1982), Plosser (1982; 1987), Makin (1983), Hoelscher (1983), Kormendi (1983), Mascaro and Meltzer (1983), Dewald (1983), Aschauer (1985), Evans (1985; 1987a; 1987b), Monadjemi (1989), Giannaros and Kolluri (1989), Darrat $(1989 ; 1990)$, and Findlay (1990) have provided empirical evidence suggesting that government budget deficits have no significant effect on interest rates. In contrast, Feldstein (1982), Hutchinson and Pyle (1984), Brath et al. (1985), Tanzi (1985), Hoelscher (1986), Tran and Swahney (1988), Wachtel and Young (1987), Kolluri and Giannaros (1987), Zahid (1988), Holloway (1988), Thomas and Abderrazak (1988a; 1988b), Allen (1990), Cebula (1990a; 1990b; 1991), and Al-Saji (1991; 1992), Liargovas et al., (1997) have found that large government budget deficits cause high interest rates. Part of the conflicting results can be explained by differences in the choice of variables, methodology and the sample period.

Furthermore, several researchers have attempted to find an association between nominal interest rates and the U.S. deficit using post-war data such as Feldstein and Eckstein (1970), Hoelscher (1986), and Cebula (1988; 1991), who show that federal deficits have a positive effect on nominal long-term interest rates, cause the slope of the yield curve to increase, and crowd out private investment. Bernhein $(1987 ; 1989)$ argues that the Ricardian equivalence hypothesis does not hold. On the other hand, Carroll and Summers (1987) find evidence to support the Ricardian equivalence hypothesis and report that there is a one-to-one link between the government deficit and private saving.

More recently, Knot and de Haan (1999) utilised the deficit announcement effect methodology to examine the relationship between budget deficits and interest rates in Germany over the period 1987-93. Their results suggested that the positive relationship between budget deficits and interest rates is due to fear that government debt may crowd out private investment (Knot and de Haan, 1999, p. 570). Ewing and Yanochik (1999) examined the impact of federal budget deficits on the term structure of interest rates in Italy over the period 1977:1-1991:3. Using the cointegration technique, this study suggested that budget deficits increase the yield spread between long-term government

${ }^{16}$ For a detailed analysis of these three paradigms see Bernheim (1989). 
bonds and the three-month Treasury bill rate. Further tests reveal the absence of any 'reverse causality', supporting the hypothesis of this study. Their findings are consistent with those of Cebula (1991) who found that US deficits exhibit a significant effect upon the term structure of interest rates. This finding suggests that budget deficits may hinder long-term economic growth in Italy, via the crowding out effect, by increasing longterm interest rates relative to short-term interest rates.

Vamvoukas (2000) examined the linkage between budget deficits and interest rates in Greece over the time periods 1949-1994, 1953-1994 and 1957-1994. Within the methodological framework of cointegration, ECM strategy, and several diagnostic and specification tests, the empirical findings support the Keynesian model of a significant and positive relationship between budget deficits and interest rates. Modeste (2000) utilised the loanable funds model of interest rate determination to investigate the relationship between budget deficits and interest rate movements. A basic tenet of that model is that interest rates would rise (fall) as economic forces either increase (decrease) the demand for loanable funds or reduce (increase) the supply of such funds. They apply their methodology (loanable funds framework and error correction) for Jamaica over the period 1964-1996. This study has found that the government's budget deficits have exerted a significant positive effect on the long-term interest rate. Adding to this result, a major implication of this study is that budget deficits, to the extent that they force up interest rates, can cause "crowding out" of private investment. As a result, as the previous event occurs, one can expect capital formation to be retarded and longterm growth to be inhibited (Modeste, 2000, pp. 676-677).

However, the next section will explain some of the econometric models used in various studies, and will be accompanied by the results of that study with respect to the relationship between the budget deficit and some macroeconomic variables.

\section{Econometric Models}

This section will review some econometric tests of economic models with respect to the impact of budget deficits on some macroeconomic variables using the ISLM model, the budget deficit and trade deficit models, the budget deficit and economic growth model, and the budget deficit and multivariable model. It is worth noting here that the models selected in this section were chosen because the results they obtained suggested a significant conclusion across a section of countries and time series; some of them used an open economy IS-LM model; they also used an important estimation technique such as VAR, and the error correction model among others.

\subsection{The IS-LM and Interest Rate Models}

Some researchers have used the IS-LM model to study the impact of a budget deficit on interest rates. It should be noted here that in the simplest and most naïve Keynesian model, increasing the budget deficit by $\$ 1$ causes output to expand by the inverse of the marginal propensity to save. In the standard IS-LM analysis of monetary economies, this expansion of output raises the demand for money. If the money supply is fixed (that is the deficit is bond-financed), interest rates must rise, and private investment falls. This in turn reduces output and partially offsets the simple Keynesian multiplier effect (Bernheim, 1989, p. 60).

The standard IS-LM model for an open economy is used by Feldstein (1982), Mascaro and Meltzer (1983), Evans (1985), Wachtel and Young (1987), Monadjemi (1989), Al-Saji (1993) among others to analyse the impact of government budget deficits upon interest rates. Evans (1985) used the IS-LM model to examine the relationship between budget deficits and interest rates. Evans surveyed U.S. economic 
history and analysed data from four periods; the civil war, WWI, WWII, and post WWII. He used the following IS-LM model:

$$
R=a_{0}+a_{1} G+a_{2} D+a_{3}(M / P)+a_{4} \pi+a_{5} U S+a_{6} U M
$$

Where, $\mathrm{R}$ is the nominal interest rate, $\mathrm{G}$ is real government spending, $\mathrm{D}$ is the real deficit, M/P is the real money stock, $\pi$ is the expected inflation rate, U.S. is an error term that measures autonomous private spending, and UM is an error term that measures autonomous money demand. Evans (1985, p. 86) concluded that "in over a century of U.S. history, large deficits have never been associated with high interest rates".

Hutchison and Pyle (1984) investigated the link between deficits and real interest rates by pooling annual time series data over the period 1973 to 1982 . The data covered the seven major industrial countries (the U.S., the U.K., France, Japan, Italy, Canada, and Germany). They used the following model:

$$
r_{t i}=b_{0}+b_{1} B_{t i}+b_{2} M_{t i}+b_{3} U_{t i}+\sum_{1}^{6} b_{3+i} D_{t i}+\mu_{t i}
$$

Where, $r_{t i}$ is the short term interest rate at time $\mathrm{t}$ in country $\mathrm{i}, B_{t i}$ is the government budget deficit (percent of GNP) at time $\mathrm{t}$ in country i, $M_{t i}$ is money growth at time $\mathrm{t}$ in country i, $U_{t i}$ is the unemployment rate at time $\mathrm{t}$ in country $\mathrm{i}, D_{t i}$ is 1 for country $\mathrm{i}$ for all $\mathrm{t}$, this dummy variable is introduced to take into account some of the institutional and structural diversity, such as tax rates, non-homogeneous inflation measures, and political instability among the industrial countries. $\mu_{t i}$ is a random error term. It is worth noting here that their methodology (formulation of their model) is consistent with both the familiar IS-LM framework and a simple loanable funds flow model of the bond and money market. Their results indicate that "short term real interest rates are systematically and positively associated with central government budget deficits across countries and across time" (Hutchison and Pyle, 1984, p. 26).

Cebula (1988) tested the conventional view that large deficits cause higher interest rates in the U.S. He regressed the nominal interest rate on Moody's Aaa-rated corporate bonds (RA) against the contemporaneous values of a number of variables, including federal deficits. Cebula argued that when examining the interest rate impact of the federal deficit, it is important to distinguish between the cyclical deficit, which is the counter-cyclically endogenous component of the total deficit, and the structural deficit, which is the exogenous component of the deficit. According to conventional macroeconomic theory the structural deficit and the cyclical deficit are both supposed to generate upward pressure on the rate of interest. Given the above remarks, he used the IS-LM based model, which is given by:

$$
N R_{t}=f\left(S D_{t} / Y_{t}, C D_{t} / Y_{t}, M_{t} / Y_{t} G_{t} / Y_{t}, P_{t}, R T R_{t}\right)
$$

Where, NR is the nominal interest rate yield on Moody's Aaa-rated corporate bonds, SD is the real structural deficits, $\mathrm{Y}$ is trend real GNP, CD is the real cyclical deficits, $\mathrm{M}$ is the change in monetary base approximated by the average of the current and preceding quarters' values of the net acquisition of credit market instruments by the Federal Reserve System, $\mathrm{G}$ is real federal government purchases of goods and services, $\mathrm{P}$ is the 
expected inflation rate during quarter $t$, expressed as a percent, RTR is the ex ante real three-month treasury bill rate, and $\mathrm{t}$ stands for time.

Cebula (1988) estimated equation (6) using seasonally adjusted data over the period 1955:1-1984:4 for the U.S. The empirical results indicated that the federal budget deficit exercises a positive and significant impact upon Moody's nominal Aaa-rated corporate bond rate. This finding contradicts most of the related literature, including Evans (1985), Makin (1983), and Hoelscher (1983). However, these findings are consistent with Barth, Iden, and Russek (1984; 1985), the study by Hoelscher (1986), and Feldstein and Eckstein (1970). He also concluded that the empirical results presented imply the actual existence of a mechanism for the transmission of crowding out. Moreover, this empirical result provides some degree of renewed confidence in standard macro-models, such as the IS-LM paradigm and the loanable funds model (Cebula, 1989, p. 209).

Al-Saji (1993) explored the impact of government budget deficits on the U.K. nominal and ex ante real long-term interest rates over the period from 1960:1 to 1990:2, utilising an open economy IS-LM model as shown below $^{17}$ :

$$
R_{t}=a_{0}+a_{1} P_{t}^{e}+a_{2} M P_{t}+a_{3} D F_{t}+a_{4} G D_{t}+a_{5} X P_{t}+e_{t}
$$

Where, $\mathrm{R}$ is the nominal long-term interest rate, $P_{t}^{e}$ is the expected rate of inflation, MP is the real money stock, DF is the real government budget deficit, GP is real government spending, $\mathrm{XP}$ is the real balance of trade, and $e_{t}$ is the usual error term. The empirical results, suggest that the variables of the expected rate of inflation, $P_{t}^{e}$, the real money stock, $M P_{t}$, and the real balance of trade, $X P_{t}$, have insignificant effects on nominal long-term interest rates. The results also reveal that the real government budget deficits variable, $D F_{t}$, exerts a significant and positive impact on nominal long-term interest rates. Furthermore, the estimated coefficient on the real government spending, $G P_{t}$, is positive and statistically significant at the $5 \%$ level.

This study found that the expected rate of inflation variable had an insignificant impact on nominal and ex ante real long-term interest rates. It was also concluded that government budget deficits, within the context of an open and closed economy IS-LM model, exert a significant and positive effect on nominal and ex ante long-term interest rates. This implies that rising nominal and ex ante real long-term interest rates, may cause "crowding out" of private investment in the U.K. and adversely affect capital formation and long-term economic growth (Al-Saji, 1993, p. 76).

Zahid (1988) studied the relationship between deficits and interest rates using quarterly data for the U.S. from 1971- to 1982. He used the following single equation technique:

$$
\Delta r=a_{0}+a_{1} \Delta D+a_{2} \Delta H+a_{3} T R E N D+a_{4} C Y C L E+u
$$

Where, $\mathrm{r}$ is the real 3-month T-bill rate, $\mathrm{D}$ is the budget deficit, alternative measures (the author used changes in outstanding publicly held government debt (i.e., borrowings

\footnotetext{
17 Al-Saji also used a closed economy IS-LM model, but this will not be reported here. For a more detailed discussion see Al-Saji (1993).
} 
from the public) as the deficit measure), TREND is the trend in nominal GNP, CYCLE is the ratio of real GNP to its trend value, and $\mathrm{H}$ is high-powered money.

Zahid found that "when the government budget deficit is defined appropriately to reflect the government excess demand for funds from the nongovernmental public, and the countercyclical variations in the deficit figures are adjusted for, then there has been a significant positive impact of deficits on the change of the real interest rate in the U.S. during the period 1971-80" (Zahid, 1988, p. 730).

Cebula and Koch (1989) examined the impact of the budget deficit on the interest rate using the following functional model:

$$
\mathrm{R}=\mathrm{R}(\mathrm{P}, \mathrm{RSR}, \mathrm{B}, \mathrm{M}, \mathrm{CI})
$$

Where, $\mathrm{R}$ is the nominal long-term interest rate, $\mathrm{P}$ is the expected future inflation rate, RSR is the expected real short-term interest rate, B is real borrowing by the U.S. Treasury, $\mathrm{M}$ is the real purchases of securities by the Federal Reserve System, and CI is the real net capital inflows into the U.S. The authors arrived at the conclusion that "federal budget deficits in the United States exercise a positive and significant influence over long-term rates of interest" (Cebula and Koch, 1989, p. 125).

Cebula and Rhodd (1993) examined the effect of budget deficits on the nominal long-term interest rates in the United States over the period of 1971:4-1985:4. They used the following functional model:

$$
\mathrm{R}=\mathrm{R}(\mathrm{P}, \mathrm{RSR}, \mathrm{B}, \mathrm{M}, \mathrm{C})
$$

Where, $\mathrm{R}$ is the nominal long-term rate of interest, $\mathrm{P}$ is the expected future inflation rate, RSR is the expected (ex ante) real short-term interest rate, $\mathrm{B}$ the real net borrowing by the federal government, $\mathrm{M}$ is real net purchases of securities by the central bank, and $\mathrm{C}$ is real net capital flows into the nation from other nations. The model adopted in this study regards the long-term nominal rate of interest as being determined by the loanable funds equilibrium of the following form:

$$
\mathrm{D}-\mathrm{S}=\mathrm{B}-\mathrm{M}-\mathrm{C}
$$

Where, $\mathrm{D}$ is real domestic private sector demand for long-term bonds, $\mathrm{S}$ is real domestic private sector supply of long-term bonds, $\mathrm{M}$ is real net purchases of securities by the central bank, $\mathrm{B}$ is real net borrowing by the federal government, and $\mathrm{C}$ is real net capital flows into the nation from other nations.

Based upon the model summarized in equation (4.10), the following equation was estimated:

$$
\mathrm{R}_{\mathrm{t}}=\mathrm{a}_{0}+\mathrm{a}_{1} \mathrm{P}_{\mathrm{t}}+\mathrm{a}_{2} \mathrm{RSR}_{\mathrm{t}}+\mathrm{a}_{3} \mathrm{~B}_{\mathrm{t}} / \mathrm{Y}_{\mathrm{t}}+\mathrm{a}_{4} \mathrm{Mt} / \mathrm{Y}_{\mathrm{t}}+\mathrm{a}_{5} \mathrm{C}_{\mathrm{t}} / \mathrm{Y}_{\mathrm{t}}+\mathrm{u}
$$

Where, $R_{t}$ is the nominal average interest rate yield in quarter $t$ on ten-year U.S. Treasury notes, expressed as a percent per annum, $a_{0}$ is the constant term, $P_{t}$ is the expected inflation rate in quarter $t$, expressed as a percent per annum, $\mathrm{RSR}_{\mathrm{t}}$ is the ex ante real average interest rate yield in quarter $t$ on three-month U.S. Treasury bills, expressed as a percent per annum, $B_{t} / Y_{t}$ is the ratio of the seasonally adjusted total federal budget deficit in quarter $t$, net of (less) debt service payments on the national debt in quarter $t$, to the seasonally adjusted middle-expansion trend GNP in quarter $t$, expressed as a percent, $\mathrm{M}_{\mathrm{t}} / \mathrm{Y}_{\mathrm{t}}$ is the ratio of $\mathrm{M}_{\mathrm{t}}$, which is defined as the average of the 
seasonally adjusted current and preceding quarters' values of the net acquisitions of credit market instruments by the Federal Reserve System, to the seasonally adjusted middle expansion trend GNP in quarter $t$, expressed as a percent, $C_{t} / Y_{t}$ is the ratio of the seasonally adjusted net flow of foreign capital into the United States in quarter t to the seasonally adjusted middle-expansion trend GNP in quarter t, expressed as a percent, and $\mathrm{u}$ is the stochastic error term. These results indicate that the federal budget deficit (net of debt service payments) exercises a positive and significant impact upon the nominal long-term rate of interest.

They concluded that "the federal budget deficit, net of debt service payments, elevates the nominal long-term rate of interest" (Cebula and Rhodd, 1993, p. 444).

Al-Khedair (1996) studied the relationship between the budget deficit and the short-term interest rate, and the long-term interest rate in the seven major industrial countries (G-7) ${ }^{18}$ over the period of 1964-1993.

This study used the following short-term and long-term interest rate models:

$$
\begin{aligned}
& I R S T=a_{0}+a_{1} B D G D P+a_{2} M S+a_{3} T B G D P+a_{4} I R S T_{t-1} \\
& I R L T=a_{0}+a_{1} B D G D P+a_{2} M S+a_{3} T B G D P+a_{4} I R L T_{t-1}
\end{aligned}
$$

Where equation (12) represents the following, IRST is the short term interest rate, BDGDP is the nominal budget deficit, MS is the money supply, TBGDP is the trade balance, and IRST ${ }_{t-1}$ is the short term interest rate, lagged one period. The model (13) was obtained by substituting the short-term interest rate and lagged short-term interest rate as specified in the first model with the long-term interest rate and the lagged longterm interest rate. Where equation (13) represents the following, IRLT is the long term interest rate, BDGDP is the budget deficit, MS is the money supply, TBGDP is the trade balance, and IRLT ${ }_{\mathrm{t}-1}$ is the long term interest rate, lagged one period.

This study found that the budget deficit leads to higher short-term interest rates in Japan and the United States. With respect to the long-term interest rate, the budget deficit led to an increase of this rate in France, Germany, and the United States (AlKhedair, 1996, p. 132).

Liargovas et al. (1997) examined the relationship between government budget deficits and interest rates in Greece over the period 1980 to 1994 by using the error correction model as follows.

$$
\begin{gathered}
M_{t}=\alpha_{0}+\alpha_{1} G D P_{t}+\alpha_{2} P_{t}+\alpha_{3} T_{B} R_{t}+\alpha_{4} R_{t}+\alpha_{5} G D E B T_{t}+\mu_{t} \\
\Delta M_{t}=\beta_{0}+\sum_{i=1}^{n 1} \beta_{1 i} \Delta M_{t-1}+\sum_{i=0}^{n 2} \beta_{2 i} \Delta G D P_{t-i}+\sum_{i=0}^{n 3} \beta_{3 i} \Delta P_{t-i}+\sum_{i=0}^{n 4} \beta 4 i \Delta T B R_{t-i} \\
+\sum_{i=0}^{n 5} \beta_{5 i} \Delta R_{t-i}+\sum_{i=0}^{n 6} \beta_{6 i} \Delta G D E B T_{t-i}+\lambda \mu_{t-1}+\varepsilon_{t}
\end{gathered}
$$

Where, $\mathrm{M}$ is the real demand for broad money (M3), GDP is the real Gross Domestic Product, $\mathrm{P}$ is the Consumer Price Index, TBR is the real T-Bill Rate reflecting the opportunity cost of holding money, $\mathrm{R}$ is the "own rate of return" representing the real Deposit Rate, and GDEBT is the real Debt of the Central Government, $\lambda$ is the error-

${ }^{18}$ Canada, France, Germany, Italy, Japan, the United Kingdom, and the United States 
correction coefficient and $\mu$ and $\varepsilon$ are random disturbance terms. The Treasury bill rate refers to the 12-month bill rate, while the deposit rate is the maximum rate offered by banks to deposits with a maturity of three to twelve months. The variables M, TBR, R and GDEBT are deflated using the CPI index. Furthermore, all variables (except for the two interest rates) are expressed in logarithms and $\Delta$ is the first-difference operator.

The author used M3, a broad measure of liquidity, as the dependent variable. Equation (14) is a long-run equilibrium money-demand function, where the parameters are largely the long-run elasticities. It is expected $\alpha_{1}, \alpha_{2}$ and $\alpha_{4}$ to be positive, $\alpha_{3}$ to be negative, while $\alpha_{5}$ might be either positive or negative. Equation (15) is a dynamic error-correction model (ECM) of the short-run behaviour of money demand, where $n_{k}(\mathrm{k}=1$ to 6$)$ measures the response of real money balances to changes in the regressors.

The author includes in the equation an impulse dummy variable D91Q1 for the first quarter of 1991, to take account of the sharp decline in broad money in that quarter as a result of the imposition of a withholding tax on interest rates from bank deposits. The deregulation of the banking system after 1992 was captured by the dummy variable D92 that takes the value of zero prior to the first quarter of 1992 and one thereafter. As can been seen from Table 4.4, all coefficient estimates have the expected signs. The variable GDEBT has a positive coefficient significantly different from 0 at the $10 \%$ level. This finding supports the Keynesian and Neoclassical hypotheses that in Greece government debt does influence interest rates via money demand. The results contradict those of Gulley (1994) for the 1980s, but are similar to Deravi's, Hegji's and Moberly's (1990) results for the period 1954:1 to 1972:4 in the U.S.

The authors arrived at the conclusion that interest rates are positively affected, both in the short-run and in the long-run (via money demand) by changes in the market value of government debt. This finding does not lend support to the Ricardian equivalence hypothesis. It is in accordance to the Neoclassical and Keynesian models, according to which government debt is viewed as net wealth (Liargovos, et al., 1997, p. $815)$.

Cebula (2000) investigated the impact of budget deficits on ex post real longterm interest rates in the U.S. over the period 1973-1995. The following equation was estimated:

$$
\operatorname{EPRLR}_{t}=a_{0}+a_{1} P C Y_{t}+a_{2} \operatorname{EARSR}_{t}+a_{3} B_{t} / Y_{t}+a_{4} C_{t} / Y_{t}+\mu
$$

Where, $a_{0}$ is constant; $E P R L R_{t}$ is the ex post real average interest rate yield in year $t$ on ten-year Treasury notes, as a percentage per annum; $P C Y_{t}$ is the change in the per capita real GDP in year t, expressed in 1987 dollars; EARSR $R_{t}$ is the ex ante real average interest rate yield in year $\mathrm{t}$ on three-month US Treasury Bills, as a percentage per annum; $B_{t} / Y_{t}$ is the ratio of the structural federal budget deficit in year $t$ to the potential GDP in year $\mathrm{t}$, as a percentage; $C_{t} / Y_{t}$ is the ratio of the net flow of foreign capital into the US in year $t$ to the potential GDP in year $t$ as a percentage, and $\mu$ is a stochastic error term.

They estimated equation (16) using instrumental variables (IV). Their results provide strong evidence that budget deficits do raise the long-term real ex post rate of interest. 


\subsubsection{The Budget Deficit and Trade Deficit Models}

Zietz and Pemberton (1990) investigated the impact of the budget deficit on the trade deficit in the U.S. They utilized a simultaneous equation model and used data from 1972:4 to 1987:2. This model is specified as below:

$$
\mathrm{S}\left(\mathrm{r}, \mathrm{ms}, p^{e}, \mathrm{df}, \mathrm{y}\right)=\mathrm{D}\left(\mathrm{r}, \mathrm{k}, p^{e}, \mathrm{y}\right)
$$

Where, $\mathrm{S}$ is the supply of bonds, $\mathrm{D}$ is the demand for bonds, $\mathrm{r}$ is the interest rate, $\mathrm{ms}$ is the money supply, $\mathrm{k}$ is the accumulated balance on current account, $p^{e}$ is the expected inflation rate, and df is the federal government budget deficit. They found that the budget deficit had a positive impact on the trade deficit.

Abell (1990b) empirically studied the linkage between the budget and trade deficits in the U.S. using data from 1979 to 1985. A vector autoregressive model (VAR) was used to test the relationship between the variables. The following national income accounting identity was used to analyse the relationship between the budget deficit and the trade deficit:

$$
\mathrm{NCF}=\mathrm{CA}=(\mathrm{G}-\mathrm{T})+(\mathrm{I}-\mathrm{S})
$$

Where, NCF is net foreign capital inflows into the U.S., CA is the current account of the balance of payments, $\mathrm{G}$ is government spending, and $\mathrm{T}$ is government tax revenue, $\mathrm{I}$ is domestic private investment spending, and $\mathrm{S}$ is domestic private saving. This study concluded that budget deficits influence trade deficits indirectly rather than directly. Evidence is obtained through causality testing and impulse response functions that the "twin deficits" are connected through the transmission mechanisms of the interest rate and exchange rate. The model indicates that reducing the size of the budget deficit may prove to be at least as effective as exchange rate intervention for the purpose of reducing the size of the merchandise trade deficit (p. 81).

Kearney and Monadjemi (1990) analysed international evidence on the impact of the budget deficit on the trade deficit from eight industrial countries over the period of 1972:1-1987:4. The primary technique used was vector autoregressive (VAR) models. The following equations were used in constructing the model:

The first equation is:

$$
Y=C_{p}+I_{p}+C_{g}+I_{g}+E X-I M+F
$$

The equation above explains how domestic output $(\mathrm{Y})$ is divided between private consumption $\left(C_{p}\right)$, private investment $\left(I_{p}\right)$, government expenditure for consumption and investment purposes ( $C_{g}$ and $I_{g}$ respectively), exports and imports of goods and services ( $E X$ and $I M$, respectively), and the interest that is payable on the country's net ownership of foreign assets $(F)$.

This identity was rewritten by defining the government's fiscal deficit (DEF) as the sum of its expenditures less tax revenue (T), and the current account balance deficit of the balance of payments (CUR), together with private savings $\left(S_{p}\right)$, which shows the following:

$$
\begin{aligned}
& \mathrm{DEF}=\mathrm{C}_{\mathrm{g}}+\mathrm{I}_{\mathrm{g}}-\mathrm{T} \\
& \mathrm{CUR}=-(\mathrm{EX}-\mathrm{IM}+\mathrm{F}) \\
& \mathrm{S}_{\mathrm{p}}=\mathrm{Y}-\mathrm{T}-\mathrm{C}_{\mathrm{p}}
\end{aligned}
$$


Substituting these definitions into the first identity yields the following twin deficit relationship:

$$
\mathrm{CUR}=\left(\mathrm{I}_{\mathrm{p}}-\mathrm{S}_{\mathrm{p}}\right)+\mathrm{DEF}
$$

This relationship describes the current account deficit in terms of the difference between private investment and savings (Ip - Sp) plus the government's fiscal deficit. The findings that emerge from their empirical analysis ${ }^{19}$ of eight countries can be summarised as indicating the existence of a temporary twin deficits relationship between the stance of fiscal policy and performance on the current account of the balance of payments, which does not persist overtime. In addition, "substantial international evidence of reverse causation is uncovered, along with the existence of complex short-term adjustment dynamics that are not invariant to the government's financing decisions, and are capable of inverting the twin deficits relationship for substantial periods of time"(Kearney and Monadjemi, 1990, 217).

Al-Khedair (1996) examined the relationship between the budget deficit and trade balance in the seven major industrial countries (G-7) over the period of 1964-1993 using the following trade balance model:

$$
\mathrm{TBGDP}=\mathrm{b}_{0}+\mathrm{B}_{1} \mathrm{BDGDP}+\mathrm{B}_{2} \mathrm{NER}+\mathrm{b}_{3} \mathrm{MS}+\mathrm{B}_{4} \mathrm{TT}
$$

Where, TBGDP is the trade balance, BDGDP is the budget deficit, NER is the nominal exchange rate, MS is the money supply, and TT is the terms of trade.

This study found that the budget deficit appeared to worsen the trade balance in Canada. In Italy and the U.S., the trade balance improved with the budget deficit. But, overall, the results indicated that the increase in the budget deficit seemed to lead to an increase in the trade balance deficit (Al-Khedair, 1996, p.132).

Mohammadi (2000) examined the empirical validity of the conventional and the Ricardian views regarding the potential impact of budget deficits on the foreign trade balance. According to the conventional view, given the path of government expenditures, substitution of budget deficits for current taxes increases the foreign trade balance deficit. In contrast, the Ricardian view suggests that the higher budget deficit is offset by an equal increase in desired private saving. Hence, the trade balance remains unaffected. The author uses cross-sectional data for a sample of 67 countries over the period 1975-95. He used the following empirical model, which captures the distinguishing features of the two theories,

$$
t b_{i}=a_{0}+a_{1} b s_{i}+a_{2} g s_{i}+a_{3} e_{i}+a_{4} g m_{i}+a_{5} g y_{i}+u_{i},
$$

Where $t b$ is a measure of the trade surplus, $b s$ is the government budget surplus, $g s$ is government expenditure, $e$ is the real exchange rate, $g m$ is the growth in money stock, gy is growth in real income, $u$ is an error term, and $\mathrm{i}(\mathrm{i}=1, \ldots, \mathrm{n})$ is a country subscript. Their empirical results indicate a positive and significant long-run link

\footnotetext{
${ }^{19}$ See Kearney and Monadjemi (1990, pp. 207-208) for details about the empirical results for the twin deficits equations for the VAR model used in their study.
} 
between the government budget surplus and the trade balance. Therefore, the data seem to strongly support the neoclassical and Keynesian prediction.

\subsubsection{Economic Growth and Other Macroeconomic Variables Models}

The impact of the budget deficit on economic growth is theoretically explained through the effect of the deficit on the flow of money into the economy and through the supply side (infrastructure, education, etc). The more that government expenditures exceed revenue the more money will be circulated in the economy, which leads to higher employment and output (McCandless, 1991).

Recent studies, for example the World Economic Outlook (IMF, 1996); concluded that during the mid-1980s a group of developing countries with high fiscal imbalances had significantly lower economic growth than countries with low to medium budget deficits. According to Shojai (1999), deficit spending that is financed by the central bank can also lead to inefficiencies in financial markets and cause high inflation in the developing countries. In addition, budget deficits distort real exchange rates and the interest rate, which in turn undermines the international competitiveness of the economy. Nevertheless, in the face of market failures, some studies have pointed to the beneficial effects of government spending on infrastructure, health, education, and productive development projects. The pioneering work of Rao (1953) indicates that government spending on productive development projects in developing countries is not as inflationary as it might be assumed because of the greater output growth. Eisner and Pieper (1987) report a positive impact of cyclically and inflation-adjusted budget deficits on economic growth in the United States and other Organization for Economic Cooperation and development (OECD) countries.

More recently, Nelson and Singh (1994) used data on a cross section of 70 developing countries during two time periods, 1970-1979 and 1980-1989, to investigate the effect of budget deficits on GDP growth rates. The GDP growth rate is used as the dependent variable. Among the explanatory variables in this study are government budget deficits, government revenue, defence spending, domestic private and public investment, population growth rate, per capita income, education, and the inflation rate. They used the following equation to estimate the relationship between growth and the public policy variables:

$$
\begin{aligned}
& G D P G=\beta_{0}+\beta_{1} D F C T+\beta_{2} D F E X+\beta_{3} G R E V+\beta_{4} P V T I N V+\beta_{5} P U B I N V \\
& +\beta_{6} P O P G+\beta_{7} E D U C+\beta_{8} I N F L+\beta_{9} D O I L+\beta_{10} P C G N P+\varepsilon
\end{aligned}
$$

Their results suggest that defence spending and private investment have had a significant positive impact on economic growth both in the 1970s and the 1980s for the countries analysed. Government revenue had a negative impact on growth. The education variable provides no conclusive effects. Public investment had a positive impact on economic growth in the 1980s but had no impact in the 1970s. This study concludes that the budget deficit had no significant effect on the economic growth of these nations in the 1970s and 1980s (Nelson and Singh, 1994, 183-184).

Burney and Akhtar (1992) empirically examined the effects of budget deficits on the exchange rate in Pakistan over the period 1971-72 to $1989-90$ by using the following functional real exchange rate model:

$$
e=f\left(\pi_{d}-\pi_{f}, T O T, Y, i_{d}-i_{f}, B D\right) f_{1}>0, f_{2}>0, f_{3}>0, f_{4}<0, f_{5}>0 \ldots \ldots
$$


Where e is the real exchange rate; $\pi_{d}$ and $\pi_{f}$ are, respectively, domestic and foreign inflation rates; TOT is the international terms of trade, i.e. export prices relative to import prices; $Y$ is level of economic activity (national income); $i_{d}$ and $i_{f}$ are, respectively, domestic and foreign interest rates; and $B D$ is the budget deficit. The equation (24) is estimated in linear form using the OLS method.

The results of this study indicate "that in the case of Pakistan, government budget deficits have influenced the real exchange rate directly as well as indirectly through the price level" (Burney and Akhtar, 1992, 879).

Roubini and Sachs (1989) studied the effects of the growth slowdown, the rise in unemployment, and the higher interest rates on the increased budget deficits after 1973 in OECD countries. They estimated a pooled cross-section time-series regression model expressed as below:

$$
d\left(b_{i t}\right)=a_{0}+a_{1} * d\left(b_{i, t-1}\right)+a_{2} * d\left(U_{i t}\right)+a_{3} * d\left(n_{i t}\right)+a_{4} * d\left(r b_{i t}\right)+a_{5} * P_{i t}+v_{i t}
$$

Where, $d\left(b_{i t}\right)$ is the annual deficit (measured as the change in the debt-GDP ratio), $d\left(b_{i, t-1}\right)$ is the lagged deficit, $d\left(U_{i t}\right)$ is the change in the unemployment rate, $d\left(n_{i t}\right)$ is the change in the GDP growth rate, $b_{i t} * d\left(r_{t}-n_{t}\right)$ is the change in the real interest rate minus the growth rate, multiplied by the lagged debt-GDP ratio, $P_{i t}$ is a political variable (an index for country $i$ at time $t$, that measures the degree of political cohesion of the national government), $v_{i t}$ is an error term, i denotes country, $t$ denotes time, and $\mathrm{d}(\mathrm{x})$ denotes the change in variable $\mathrm{x}$.

The results of this study suggested " the shocks that hit the macroeconomies of the industrial countries, particularly slower growth and higher unemployment after 1973, and higher real interest rates in the 1980s, all contributed to a jump in the budget deficits of the industrial countries" (Roubini and Sachs, 1989, p. 922).

Arora and Dua (1993) studied the effects of budget deficits on investment and on trade deficits during the period from 1980 to 1989 . They utilized the following functional model:

$$
X_{t}=f(D / Y, m, y, e)
$$

Where, $\mathrm{X}_{\mathrm{t}}$ is the dependent variable, $\mathrm{D} / \mathrm{Y}$ is the ratio of the budget deficit to GNP, Y is GNP, $m$ is the percentage change from the previous period in real GNP, and $e$ is the percentage change from the previous period in the real exchange rate. This study suggests that "higher budget deficits crowd out domestic investment and increase trade deficits"(Arora and Dua, 1993, p. 42).

Karras (1994) studied the effects of budget deficits on money growth, inflation, investment, and real output growth. He used pooled annual data from 32 countries covering periods from the 1950s to the 1980s. This study concludes that deficits do not lead to inflation through monetary expansion; deficits are negatively correlated with the rate of growth of real output; and increased deficits do appear to retard investment usually after one or two years.

Al-Khedair (1996) studied the relationship between the budget deficit and economic growth in the seven major industrial countries (G-7). The data utilized in this study covered the period from 1964 to 1993 . He used the following economic growth model: 


$$
\mathrm{EG}=\mathrm{c}_{0}+\mathrm{c}_{1} \mathrm{BDGDP}+\mathrm{c}_{2} \mathrm{MS}+\mathrm{c}_{3} \mathrm{NER}+\mathrm{C}_{4} \mathrm{TT}+\mathrm{c}_{5} \mathrm{FDIGDP}
$$

Where, EG is economic growth, BDGDP is the budget deficit, MS is the money supply, NER is the nominal exchange rate, and FDIGDP is foreign direct investment. He found that the budget deficit has a significant positive impact on economic growth in France, Germany, and Italy.

Overall results concluded that the budget deficit seems to positively and significantly affect economic growth in all the seven major industrial countries (AlKhedair, 1996, p. 132).

\section{Summary and Conclusions}

In summary, this paper has reviewed the extensive literature examining the relationship between budget deficits and economic variables, concentrating on theoretical debates, empirical studies, and econometric models. It can be concluded from the empirical studies (e.g. Barro (1991); Arora and Dua (1993); Nelson and Singh (1994); Kelly (1997); Aschauer (1989b); Argimon et al. (1997); Ghali and Al-Shamsi (1997); Bahmani (1999); Ahmed and Miller (2000); among others) presented in this papare dealing with the impact of public investment on private investment and economic growth, that one of the important outcomes from these studies showed that cross-section analysis cannot capture the country specific nature of the government spending and growth relationship. Moreover, time series analysis reveals the causal relationship between variables, while cross-section analysis can identify correlation but not causation between variables.

In general the key outcomes from the studies presented in this chapter indicated that both the method of financing and the components of government expenditure could have different effects. Therefore, it is crucial to distinguish between current and capital expenditure when evaluating the impact of fiscal policy on private investment and output growth. Thus, overall results from the empirical literature with respect to the impact of public investment on private investment and growth are ambiguous but the bulk of the empirical literature finds a significantly negative effect of public consumption expenditure on growth, while the effects of public investment expenditure are found to be positive although less robust.

The major outcomes from the empirical studies (e.g. Dwyer (1982); Darrat (1985); Ahking and Miller (1985); Choudhary and Parai (1991); Dogas (1992); Hondroyiannis and Papapetrou (1994); Karras (1994); Metin (1998), Darrat (2000); among others) examining the relationship between budget deficits and inflation, showed strong evidence that the budget deficit financed through monetisation and a rising money supply could lead to inflation. However, the inflationary effect of government deficits depends upon the means by which the deficit is financed and the impact of that on aggregate demand.

The evidence from a range of detailed studies (e.g. Volker (1984); Laney (1986); Bundt and Solocha (1988); Evans (1988); Abell (1990b); Kearney and Monadjemi (1990); Tallman and Rosensweig (1991); Bachman (1992); Arora and Dua (1993); Kasa (1994); Al-Khedair (1996); Islam (1998); Khalid and Guan (1999); Egwaikhide (1999); Piersanti (2000); among others) with respect to the impact of the budget deficit on the trade deficit (the twin-deficit), reported in this chapter, has been mixed. The methodology used to analyse the above issue varies from well-specified theoretical models to using a simple one-to-one relationship between the budget deficit and current account deficit. Furthermore, the empirical findings investigating the relationship 
between budget deficits and trade deficits are ambiguous, as are the theoretical ones, in both developed and developing countries. Even though the overall results are inconclusive, it is worth noting here that the majority of these studies found evidence towards supporting the twin deficits relationship arising through the exchange rate. Thus the key outcome from all of these studies indicated strong evidence towards supporting the Keynesian proposition (conventional view) which suggests that an increase in the budget deficit would induce domestic absorption and, hence import expansion, causing a current account deficit.

Empirical investigations (e.g. Bundt and Solocha (1988); Burney and Akhtar (1992); Bohn (1992); Meltzer (1993); Hakkio (1996); Stoker (1999); among others) of the impact of budget deficits on the exchange rate are as inconclusive as the theoretical arguments. The major conclusion from the empirical studies examining the relationship between the budget deficit and the exchange rate showed strong evidence, in both developed and developing countries, generally supporting the conventional macroeconomic theory, rather than the Ricardian equivalence proposition which holds that large deficits have no real adverse macroeconomic effects. It can also be concluded from the empirical findings that the effects of budget deficits on exchange rates depends on the way of funding the deficits, whether through taxation or through money growth.

In addition, as we have seen in this paper, many studies examined the relationship between the budget deficit and interest rates by using an IS-LM framework among other models such as the loanable funds model. The evidence from a range of detailed studies (e.g. Feldstein (1982); Dwyer (1982); Evans (1985); Makin (1983); Aschauer (1985); Mascaro and Meltzer (1983); Hutchison and Pyle (1984); Monadjemi (1989); Cebula (1988); Giannaros and Kolluri (1989), Findlay (1990); Al-Saji (1993); Cebula and Rhodd (1993); Al-Khedair (1996); Liargovas et al. (1997); Knot and de Haan (1999); Vamvoukas (2000); Modeste (2000); Cebula (2000); among others) with respect to the impact of the budget deficit on interest rates are mixed. Part of the conflicting results can be explained by differences in the choice of variables, methodology and the sample period. Thus, the key outcomes from the empirical studies investigating such a relationship indicated strong evidence towards supporting the Keynesian model of a significant and positive relationship between budget deficits and interest rates.

Thus, it can be concluded from this paper that, ironically, the empirical evidence does not shed any definitive light on the relationship between the budget deficit and economic variables, as with the theoretical analysis. Overall, from the studies presented in this paper, with respect to the relationship between the budget deficit and economic variables, the evidence is inconclusive. It seems that, depending on how the budget is measured, the econometric model adopted, the econometric technique/methodology adopted, and the period/country of study, different conclusions can be reached. 


\section{References}

Abell, John D., (1990a), "The Role of the Budget D eficit during the Rise in the D ollar Exchange Rate from 1979-1985", SathemEcommicJaumal, Vol. 57, No. 1, pp. 66-74.

— . (1990b), "Twin Deficits During the 1980s: An Empirical Investigation", Jaumal of Marceconomics pp. 81-96.

Abizadeh, S. and Yousefi, M., (1986), "Political Parties, Deficits, and the Rate of Inflation: A Comparative Study", Jaumal of Soial, Pditical and Economic Studies Vol. 11, pp. 393-411.

Abizadeh, S., Yousefi, M., and Benarroch, M., (1996), "A Multilevel Government Model of D eficits and Inflation", AtlanticEconomicJaumal, Vol. 24, pp. 118-130.

Ahking, F. W., and Miller, S. M., 1985, "The Relationship Between Government Deficits, Money Growth and Inflation" Jaumal of Macroeconomics Vol. 7, pp. 447-467.

A hmed, H. and Miller, S. M. (2000), "Crowding-out and Crowding-in Effects of the Components of Government Expenditure", Contemparary EconomicPdig, Vol.18, No. 1, pp. 124-133.

Aiyagari, R., Christiano, L., and Eichenbaum, M. (1992), "The O utput, Employment, and Interest Rate Effects of G overnment Spending", Jarmal of MondaryEconomics", Vol. 30, pp. 73-86.

Al-Khedair, Saleh I. (1996), "TheImpad of the Budgt Defiat on Key Macroeconomic variables in the Major Industrial Cantries", Ph.D . D issertation, Florida A tlantic University.

Allen, Polly, R. (1977), "Financing Budget Deficits: The Effects on Income in Closed and Open Economies", Eurqpeen EconomicReiew Vol. 10, pp.345-373.

Allen, S. D., (1990), "The Effect of Federal Deficits and Debt on the Tax-Adjusted, Short-Term, Real Interest Rates", Economics Lettes Vol. 34, No. 2, pp. 169-73.

Argimon, I. et al. (1997), "Evidence of Public Spending Crowding-O ut from a Panel of OECD Countries", AppliedEconomics Vol. 29, pp. 1001-1011.

Al-Saji, Amer K. (1991), "The Effect of Government Budget Deficits on Real Interest Rates: Empirical Evidence from Italy, 1960:1-1990:2", Rivista Intemezianale Di Saieze Economide E Commadiali, Vol. 38, No. 10-11, pp. 871-8.

. (1992), "The Impact of Government Budget Deficits on Ex Post Real Long Term Interest Rates in the U.K., 1960:1-1990:2", Economia Intemezionale Vol. X LV, No. 2, pp. 158-63.

. (1993), "G overnment Budget D eficits, Nominal and Ex Ante Real Long-Term Interest Rates in the U.K., 1960:1-1990:2", AtlanticEconomicjamal, Vol. 21, pp. 71-77.

Arora, H. and Dua, P. (1993), "Budget Deficits, Domestic Investment, and Trade Deficits" Contemporary Pdioy Issues Vol. 11, pp. 29-44.

Aschauer, D. A. (1985), "Fiscal Policy and Aggregate Demand", American Economic Reiew Vol. 75, No. 1, pp. 117-27. 
_ . (1989a), "Is Public Expenditure Productive?" Jarmal of Mondary Econamics Vol. 23, pp. 177200.

. (1989b), "D oes Public Capital Crowd O ut Private Capital?" Jamal of Mantary Economics Vol. 24, pp. 171-188.

Bachman, D. (1992), "Why Is the U.S. Current Account Deficit So Large? Evidence from Vector Autoregressions", Satthem EconomicJaumal, Vol. 59, pp. 232-240.

Ball, L. and Mankiw, N. G. (1995), "What Do Budget Deficit Do?”, Working Paper, No. 5263, National Bureau of Economic Research, Cambridge, pp. 1-36.

Bahmani, O. M. (1999), "The Federal Budget Deficits Crowd Out or Crowd In Private Investment?", Jamal of PdigyModling Vol. 21, No. 5, pp. 633-40.

Bailey, M. (1971), "Natimal Incomeand thePriveLede", McG raw-Hill.

Barro, Robert J. (1974), "Are G overnment Bonds Net Wealth?”, Jarmal of Pditical Economy, Vol. 82, pp. 1095-1117.

. (1978), "Comment from an Unreconstructed Ricardian", Jaumal of MondaryEconomics Vol. 4, pp. 569-81.

. (1979), "On the Determination of the Public Debt', Jamal of Pditical Ecanomy, Vol. 87, pp. 240-71.

_ . (1981), "O utput Effects of Government Purchases", Jaumal of Pditical Economy, Vol. 89, pp. 1086-1121.

—_ . (1989), “Rational-Expectationist”, National Reiew Vol. 41, pp. 49-50.

. (1989), "The Ricardian Approach to Budget D eficits", Jamal of Econamic Pespetives Vol. 3, pp. 37-54.

. (1990), "Government Spending in a Simple Model of Endogenous Growth", Jarmal of Pditical Economy, Vol. 98, S103-S125.

. (1991), "Economic Growth in a Cross Section of Countries", Quartely Jamal of Econamiss Vol. 106, pp. 407-444.

Barth, J. R., Iden, G., and Russek, F. S. (1984), "D o D eficits Really Matter?”, Contemporary Pdioy Issues Vol. 3, No. 1, pp. 79-95.

— - , and — . (1986), "The Economic Consequences of Federal Deficits: An Explanation of the Net Wealth and Instability Issues', Sathem EconamicJaumal, Vol. 53, No. 1, pp. 27-50.

, and (1985), Federal Borrowing and Short Term Interest rates: Comment", SathemEconmicJamal, Vol. 52, No. 2, pp. 554-59. 
Bernheim, B. D. (1987), "Ricardian Equivalence: An Evaluation of Theory and Evidence” in Fisher, S. (ed.), “NBER Macoeconomics Annual”, MIT Press, Cambridge, Mass., pp. 263-303.

Bernheim, B. D. (1989), "A Neoclassical Perspective on Budget Deficits", Jaumal of Econamic Pespeetives Vol. 3, pp. 55-72.

Bhalla, S. S. (1981), "The Transmission of Inflation Into D eveloping Economies" in W. R. Cline and Associates (eds.), "Wodd Inflation and the Dexdoping Cantres", Brookings Institution, Washington, D C, pp. 52-101.

Bisignano, J and Kevin D. Hoover (1982), "Monetary and Fiscal Impacts on Exchange Rates", EconamicReviev(Federal Reserve Bank of San Francisco), pp. 19-33.

Bohn, H. (1992), "Budget Deficits and Government Accounting", Conference Proceedings. Carnegie Rochester Conference Series on Public Policy, pp. 1-83.

Bolbol, Ali A. (1999a), "Seigniorage, D ollarization and Public D ebt: The Lebanese Civil war and Recovery Experience 1982-97”, WoddDedqpment, Vol. 27, No. 10, pp.1861-1873.

. (1999b), "D eficits, D ebt and Post-War Lebanon: Analysis and Policy Proposals", Economics D epartment, Ryerson Polytechnic University, Toronto.

Boyer, R. S. (1978), "Currency Mobility and Balance of Payments Adjustment", in Putnam, B. and Wilford, D. S. (Eds.), Praeger.

Branson, William H. (1985), "Causes of Appreciation and Volatility of the Dollar" in "The U.S. Ddlar-Reent Deddqments, Outlok, and Pdigy Options", Federal Reserve Bank of Kansas City, Kansas.

Branson, William H., Halttunen, H. and Masson, P. (1977), "Exchange Rates in the Short Run: The D ollar-D eutschemark Rate", Europeen EconamicReview Vol. 10, pp.303-324.

Brath, J. et al. (1985), “D o Federal D eficits Really Matter?”, ContempararyPdigy Issues Vol. III, No. 1, pp. 79-95.

Buchanan, J. and Wagner, R. (1977), “Demorayin defiat: ThePditical Leeagy of Lord Keynes”, A cademic Press, New York.

Buiter, W. H. (1977), "Crowding O ut and the Effectiveness of Fiscal Policy", Jaumal PublicEconamis pp. 309-328.

Buiter, W. H. and Patel, U. R. (1992), "D ebt, D eficits, and Inflation: An Application to the Public Finances of India", Jaumal of PublicEconomics Vol. 47, pp. 171-205.

Bundt, T. and Solocha, A. (1988), "D ebt, D eficits. And D ollar", Jaumal of Pdig Moddling Vol. 10, No. 4, pp. 581-600.

Burney, N. A. and Akhtar, N. (1992), "Government Budget Deficits and Exchange Rate Determination: Evidence from Pakistan", ThePakistan Dedopment Review Vol. 31, No. 4, pp. 871-882. 
Carroll, C. and Summers, L. H. (1987), "Why Have Private Savings Rates in the United States and Canada Diverged?", Jaumal of Mandary Econamics pp. 249-279.

Cebula, R. (1988), "Federal Government Budget D eficits and Interest Rates: A Brief Note”, Sathem EconamicJaumal, Vol. 55, No. 1, pp. 206-210.

Cebula, R. J. (1990a), "Federal Government Borrowing and Interest Rates in the U.S.: An Empirical Analysis Using the IS-LM Framework", Econamia Intemazianale, Vol. X LIII, No. 2-3, pp. 15964.

— (1990b), "Federal Government Deficits and the Term Structure of Interest Rates in the U.S.”, Rivista IntemezianaleDi SaieneE EconamideE Commeriali, XXXVII, Vol. 10-11, pp. 93744.

. (1991), "A Note on Federal Budget D eficits and the Term Structure of Real Interest Rates in the United States" SauthemEconomicJaumal, pp. 1170-1173.

. (2000), "Impact of Budget Deficits on Ex Post Real Long-Term Interest Rates", Applied Econamics Letters Vol. 7, No. 3, pp. 177-79.

Cebula, R. J. and Koch, J. (1989), “An Empirical Note on D eficits, Interest Rates, and International Capital Flows”, Quartely Reviewof Economiss andBusiness Vol. 29, pp. 121-127.

Cebula, R. J. and Rhodd, R. (1993), "A Note on Budget Deficits, debt Service Payments, and Interest Rates”, TheQuartely Reviewof Economics andFinance, Vol. 33, pp. 439-445.

Chinn, M., (1991), "Some Linear and Non-linear Thoughts on Exchange Rates", Jamal of Intemational Moneyand Finame, pp. 214-230.

Choudhary, M. A. S. and Parai, A. K. (1991), "Budget Deficit and Inflation: The Peruvian Experience”, AppliedEconamis Vol. 23, pp. 1117-1121.

Crozier, Robert B. (1976), "D eficit financing and Inflation: Facts and Fiction”, Occasional Papers, No. 3, Conference Board of Canada.

Cuddington, J. T. (1983), "Currency Substitution, Capital Mobility, and Money D emand”, Jaumal of Intemational Moneyand Finame, V ol. 2, pp. 111-133.

Daniel, B. C. (1985), "Monetary Autonomy and Exchange Rate Dynamics Under Currency Substitution", Jaumal of Intemational Economics Vol. 19, pp. 119-139.

Darrat, A. F. (1985), "Inflation and Federal Budget D eficits: Some Empirical Results", PublicFinance Quartely, Vol. 13, pp. 206-215.

. (1988), "Have Large Budget Deficits Caused Rising Trade Deficits?", Sauthem Econamic Jaumal, Vol. 55, pp. 879-887.

. (1989), "Fiscal D eficits and Long-Term Interest Rates: Further Evidence from Annual D ata”, SauthemEconamicJaumal, Vol. 56, No. 2, pp. 363-74 
. (1990), "Structural Federal Deficits and Interest Rates: Some causality and Co-Integration Tests", Sauthem EconamicJaumal, Vol. 56, No. 3, pp. 752-9.

. (2000), "Are Budget D eficits Inflationary? A Reconsideration of the Evidence", Applied Econamics Vol. 7, No. 10, pp. 633-36.

D avid, P. A. and Scadding, J. L. (1974), "Private Savings: Ultrarationality, aggregation, and D enison's Law", Jaumal of Pditical Economy, Vol. 82, pp. 225-250.

D eravi, M. K., Hegii, C. E., and Moberly, M. D ., (1990), "Government Debt and the Demand for Money: An Extreme Bound Analysis”, EconamicEnquiry, Vol. 28, pp. 390-401.

D evereux, M. B. and Love, D. R. F. (1995), "The Dynamic Effects of Government Spending Policies in a Two-Sector Endogenous Growth Model", Jaumal of Maney, Creedit, and Banking Vol. 27, No. 1, pp. 232-256.

D ewald, W. (1983), "Federal deficits and Real interest Rates: Theory and Evidence", EconomicReiew Federal Reserve Bank of Atlanta, Vol. LXVIII, No. 1, pp. 20-9.

Dogas, D. (1992), "Market Power in a Non-monetarist Inflation Model for Greece" Applied Economics Vol. 24, pp. 367-378.

D ornbusch, R. and Fisher, S. (1981), "Budget D eficits and Inflation" in M.J. Flanders and A. Razin (eds.), "Dedeqment in anInflationaryWodd", Academic Press, New Y ork

Dua, P., (1993), "Interest rates, Government Purchases, and Budget D eficits: A Forward-Looking Model”, PublicFinameQuartery, Vol. 21, pp. 470-478.

Dwyer, Gerald P. (1982), "Inflation and Government Deficits", Economic Inquiry, Vol. XX, pp. 315-329.

Edwards, S. (1989), "Real ExdhangeRates, Devaluation, andAdjustment: Exdhange RatePdigyin Devdquing Cauntries", Mass.: MIT Press, Cambridge,

Egwaikhide, F. O. (1999), "Effeets of Budge Defiat on Trade Balancein Nigeia: A Similation Execise", African Dedqument Reiew Vol. 11, No. 2, pp. 265-89.

Eisner, R. (1986), “HowReal IsTheFedaral defiat?", Free Press, New York.

_ . (1989), "Budget D eficits: Rhetoric and Reality", Jaumal of EconomicPerspeetives Vol. 3, pp. 7393.

_ . (1989), “Liberal Keynesian', National Review Vol. 41, p. 47

_ . (1991), "The Deficits and Us and Our Grandchildren” in James M. Rock (ed.), "Dedtandthe TwinDefiatsDebate', Mayfield Publishing Co., Mountain View, pp. 81-107.

Eisner, R. and Pierper, Paul J. 1984, "A New View of the Federal Debt and Budget Deficits", American EconamicReview Vol. 74, pp. 11-29. 
- . (1987), "Measurement and Effects of G overnment D ebt and D eficits" in B. Jacquillat, A. W. Sametz, M. Sarnat, and G.P. Szego, (eds.), "EcommicPdigy and National Accountingin Inflationary Conditions", Studies in Banking and Finance, Amsterdam: North-Holland.

Enders, W. and Lee, B. S. (1990), "Current Account and Budget Deficits: Twins or Distant Cousins?", Reiiewof Economics and Statistics pp. 373-381.

Engel, C. and Hamilton, J. D. (1990), "Long Swings in the Dollar: Are They in Data and Do Markets Know it?", Ameican EconomicReiew pp. 689-713.

Evan, P. (1985), "Do Large Budget Deficits Produce High Interest Rates?", American Economic Reiew Vol. 75, No. 1, pp. 68-87.

(1987a), "Interest Rates and Expected Future D eficits in the U.S.", Jaumal of Pditical Economy, Vol. 95, No. 1, pp. 34-55.

(1987b), "D o Budget D eficits Raise Nominal Interest Rates? Evidence from Six Countries", Jaumal of Montary Economics Vol. 20, No. 2, pp. 281-300.

. (1988), "Do Budget Deficits Affect the Current Account?" Unpublished, Ohio State University, $\mathrm{O}$ hio.

Ewing, B. T. and Yanochik, M. A. (1999), "Budget D eficits and the Term Structure of Interest Rates in Italy", AppliedEconmics Lettes Vol. 6, pp. 1999-201.

Feldstein, M. (1982), "Government D eficits and Aggregate D emand", Jaumal of Mandary Economics Vol. 9, No. 1, pp. 1-20.

Feldstein, M. and Eckstein, O. (1970), " The Fundamental Determinants of the Interest Rate", Reiewof Economiss and Statistics pp. 363-375.

_ . (1992), "The Budget and Trade D eficits A ren't Really Twins", Challenge pp. 60-63.

Feldstein, M. and Horioka, C (1980), "D omestic Saving and International Capital Flows", Econmic Jamal, pp. 314-329.

Fieleke, Norman S. (1987), "The Budget deficit: Are the International Consequences Unfavourable?" in R. Fink and J. High (eds.), "A Nation in Dedt: Economists Debatethe Fedaral Budgt Defiat", Maryland: University Publications of America, Fredrick. pp. 171-180.

Findlay, D. W. (1990), "Budget deficit, Expected Inflation, and Short-Term Real Interest Rates: Evidence from the U.S.", Intemational EconmicJaumal, Vol. 4, No. 3, pp. 41-53.

Fleming, J. M. (1962), "Domestic Financial Policies Under Fixed and Under Floating Exchange Rates", Intemational Montary Fund Staff Papess No. 10, pp. 369-380.

Floyd, J. (1969), "Monetary and Fiscal Policy in a World of Capital Mobility", Review of Economic Studies Vol. 36, pp. 503-518.

Frenkel, Jacob A. and Razin, A. (1987), "Fiscal Pdicies and the Wodd Economy. An Intetemparal Approad", Mass.: MIT Press, Cambridge. 
Friedman, M. (1968), "The Role of Monetary Policy", American EconmicReiew Vol. 58, pp. 1-17.

Friedman, B. M. (1978), "Crowding out or Crowding in? Economic Consequences of Financing G overnment deficits", Brodkings Papers on EconomicAdivity, No. 3, pp. 593-641.

Ghali, Khalifa H. (1997), "Government Spending and Economic Growth in Saudi Arabia", Jaumal of Dedqpmet Economics Vol. 22, No. 2, pp. 165-72.

. (1998), "Public Investment and Private Capital Formation in a Vector Error-Correction Model of Growth", AppliedEcanomics Vol. 30, No. 6, pp. 837-844.

G hali, K. and Al-Shamsi, F. (1997), "Fiscal Policy and Economic Growth: A Study Relating to the United Arab Emirates", Economia Intemezional, Vol. 50, No. 4, pp. 519-33.

Giannaros, D. S. and Kolluri, B. R. (1989), "The Impact of Budget D eficits on Real Interest Rates: An International Empirical Investigation", Intemational EconomicJamal, Vol. 3, No. 2, pp. 1725.

Giffen, P. E., McComber J. H. and Berry, E. B. (1982), "An Empirical Examination of Current Inflation and Deficit Spending", Jamal of Pot KenesianEconomics Vol. 4, pp. 63-67.

Girton, L. and Henderson, D. W. (1976), "Financial capital Movements and Central Bank Behaviour in a Two-Country, Short-Run Portfolio Balance Model", Jaumal of Mondary Economiss Vol. 2, pp. 33-61.

Guess, G. and Koford, K. (1984), "Inflation, Recession and the Federal Budget D eficit (or, Blaming Economic Problems on A Statistical Mirage)", PdigySiences Vol. 17, pp. 385-402.

Gully, D. (1994), "An Empirical Test of the Effects of Government D eficits on Money demand", AppliedEconomics Vol. 26, pp. 239-47.

Hall, R. (1980), "Labour Supply and Aggregate Fluctuations", Carnegie Rochester Conference Series on Public Policy, No. 12, pp. 7-33.

Hafer, R. W. and Hein, S. E. (1988), "Further Evidence on the Relationship between Federal Government D ebt and Inflation", EconomicInquiry, Vol. 26, pp. 239-251.

Hakkio, S. and Joines, D. (1990), "Real and Nominal Exchange Rates since 1919", Working Paper, Federal Reserve Bank of Kansas City.

Hakkio, Craig S. (1996), "The Effects of Budget D eficit Reduction on the Exchange Rate", Econmic Reiew(Federal Reserve Bank of Kansas City), Vol. 81, No. 3, pp. 21-38.

Hamburger, M. J. and Zwick, B. (1981), "D eficits, Money and Inflation", Jamal of Montary Economics Vol. 7, pp. 141-150.

Heng, T. K. (1997), "Public Capital and Crowding in", TheSingapareEconomic Reriew Vol. 42, No. 2, pp. 1-10. 
Hoelscher, G. P. (1983), "Federal Borrowing and Short-Term Interest Rates", Sathem Economic Jamal Vol. 50, No. 2, pp. 319-33.

_ (1986), "New Evidence on D eficits and Interest Rates", Jaumal of Money, Creeit, and Banking pp. 1-17.

Holloway, T. M. (1988), "The Relationship Between Federal Deficit/ D ebt and Interest Rates", The AmericanEconomist, XXXII, Vol. 1, pp. 29-38.

Hondroyiannis, G. and Papapetrou, E. (1994), "Cointegration, Causality and Government BudgetInflation Relationship in Greece", Applied EconomicLettes Vol. 1, pp. 204-206.

Huizinga, J. (1987), "An Empirical Investigation of the Long-run Behaviour of Exchange Rates", Conference Proceedings. Carnegie Rochester Conference series on Public Policy, pp. 149-214.

Humpage, O. F., (1992), An Introduction to the International Implications of U.S. Fiscal Policy", EconamicReiew(Federal Reserve Bank of Cleveland), Vol. 28, No. 3, pp. 27-39.

Hutchison, M. M. and Charles Pigott (1984), "Budget Deficits, Exchange Rates, and the Current Account: Theory and U.S. Evidence", Econmic Reiew (Federal Reserve Bank of San Francisco), pp. 5-25.

Hutchison, M. M. and Pyle, D. H. (1984), "The Real Interest Rate/ Budget Deficits Link: International Evidence, 1973-82", EconomicReiew Federal reserve Bank of San Francisco, Vol. 4, pp. 26-35.

Hutchison, M. M. and Adrian W. Throop (1985), "U.S Budget deficits and the Real Value of the D ollar", Economicreiew(Federal Reserve Bank of San Francisco), pp. 26-43.

International Monetary Fund, 'TMF” (1996), “WoddEconomicOutlok", Washington, D . C.

Islam, M. F. (1998), "Brazil's Twin Deficits: An Empirical Examination”, Atlantic EconomicJaumal, Vol. 26, No. 2, pp. 121-128.

Karras, G. (1994), "Macroeconomic Effects of Budget Deficits: Further International Evidence", Jaumal of Intemational Money andFinance, Vol. 13, pp. 190-210.

Kasa, K. (1994), "Finite Horizons and the Twin D eficits", EconomicReiew(Federal Reserve Bank of San Francisco), No. 3, pp. 19-28.

Kearney, C. and Monadjemi, M. (1990), "Fiscal Policy and Current Account Performance: International Evidence on the Twin D eficits", Jaumal of Macroeconomics Vol. 12, pp. 197-220.

Kelly, T. (1997), "Public Expenditures and Growth", Jamel of Dexdqpment Studies Vol. 34, No. 1, pp. 60-84.

Khalid, A. M. and Guan, T. W. (1999), "Causality Tests of Budget and Current Account Deficits: Cross-Country Comparisons", Empirical Economics Vol. 24, No. 3, pp. 389-402.

King, R. E. and Rebelo, S. T. (1990), "Public Policy and Economic Growth: Developing Neoclassical Implication", Jaumal of Pditical Eanmy, Vol. 21, pp. 309-41. 
Knot, K. and de Haan, J. (1999), "D eficit Announcement and Interest Rates: Evidence for Germany”, Jaumal of Pdigy Moddling", Vol. 21, No. 5, pp. 559-77.

Kolluri, B. R. and Giannaros, D. S. (1987), "Budget Deficits and Short-Term Real Interest Rates Forecasting", Joumal of Macroeconomics Vol. 9, No. 1, pp. 109-25.

Kormendi, R.C. (1983), "Government Debt, Government Spending, and Private Spending Behaviour", American Econamic Review Vol. 73, No. 5, pp. 994-1010.

Kormendi, R. C. and P. G. Meguire (1985), "Macroeconomic Determinants of Growth: CrossCountry Evidence", Jaumal of Montary Econamics Vol. 16, pp. 141-63.

Kouri, Penniti J. K. (1976), "The Exchange Rate and the Balance of Payments in the Short-Run and in the Long Run: A Monetary Approach", Scandinavian Jaumal of Economics Vol. 78, pp. 280304.

Landau, D. (1983), "Government Expenditure and Economic Growth: As Cross-Country Study", Sauthem EconomicJaumal, Vol. 49, pp. 783-97.

Laney, L. (1986), “Twin D eficits in the 1980s: What are the Linkages?”, BusinessEcanmics pp. 40-45.

Langdana, F.(1990), SustainingBudgt Defiatsin OpenEcanomies Routledge, New York.

Liargovas, P. et al. (1997), "The Relationship Between Government Budget Deficits and Interest Rates in Greece", Intemational Reviewof Ecomamis andBusiness Vol. 44, No. 4, pp. 807-17.

Makin, J. (1983), "Real Interest, Money Surprises, Anticipated Inflation, and Fiscal Deficits”, The Reviewof Economiss and Statistics Vol. LXV, No. 3, pp. 347-84.

Martson, R. C. (1980), "Cross Country Effects of Sterilization, Reserve Currencies, and Foreign Exchange Intervention", Jaumal of Intemational Econamics Vol. 10, pp. 63-78.

Mascaro, A. and Meltzer, A. H. (1983), "Long-and Short-Term Interest Rates in a Risky World", Jamal of Montary Economics Vol. 12, No. 4, pp. 485-518.

McCallum, B. T. (1984), “Are Bond-Financed D eficits Inflationary? A Ricardian A nalysis”, Jaumal of Pditical Economy, Vol. 92, No. 1, pp. 123-35.

McCandless, G. (1991), "MacroeconamicTheery”, Englewood Cliffs, New Jersey: Prentice Hall.

McKinnon, R. C. (1982), "Currency Substitution and Instability in the World Dollar Standard", AmericanEconomicReview Vol. 72, pp. 320-333.

. (1984), "An International Standard for Monetary Stabilization", in "Pdig Analysis in Intemational Economis". Washington, D . C.: Institute for International Economics, Vol. 8.

McMillan, W. D. and Beard, T. R. (1982), "D eficits, Money and Inflation”, Jaumal of Montary Econamics Vol. 10, pp. 273-277.

Meese, R. and Rogoff, K. (1983), "Empirical Exchange Rate Models of the Seventies: D o They Fit O ut of Sample?", Jaumal of Intemational Economics pp. 3-24. 
Meltzer, A. H. (1989), “Monetarist”, National Reiew Vol. 41, pp. 47-48.

Metzler, L. A. (1951), "Wealth, Saving, and the Rate of Interest", Jaumal of Pditical Economy, Vol. 59, pp. 93-116.

. (1993), "Real Exchange Rates: Some Evidence from the Post-war Years", Economic Reiew (Federal Reserve Bank of St. Louis), pp. 103-117.

Metin, K. (1995), "An Integrated Analysis of Turkish Inflation", Oxford Bullein of Econmics and Statistics Vol. 57, pp. 513-533.

. (1998), "The Relationship Between Inflation and the Budget Deficit in Turkey", Jaumal of Business andEcomomicstatistics Vol. 16, No. 4, pp. 412-22.

Miller, P. (1983), "Higher Deficit Policies Lead to Higher Inflation", Quartery Reien Federal Reserve Bank of Minneapolis, pp. 8-19.

Miller, S. M. (1980), "Dynamic Monetary and Fiscal Policy and the Government Budget Constraint: A G rowth Equilibrium", Jaumal of Macoeecnomics Vol. 2, No. 3, pp. 199-212.

Miller, S. M. and Russek, F. S. (1997), "Fiscal Structures and Economic Growth", EconomicInquiry, Vol. 35, pp. 603-613.

Modeste, N. C. (2000), "The Impact of Budget Deficits on Long-Term Interest Rates in Jamaica, 1964-1996: An Application of the Error Correction Methodology", Intemational Rexiew of Economics and Business Vol. 47, No. 4, pp. 667-78.

Modigliani, F. (1983), "Government Deficits, Inflation, and Future Generations" in David, W. Conklin and Thomas J. Courchence (eds.), "Defiats, Money and Inflation: HowBigand HowBad", Special Research Report, Toronto: Ontario Economic Council, pp. 55-71.

Mohammadi, H. (2000), "Budget D eficits and the Foreign Trade Balance: A Cross-Country Study", Economia Intemazionale, Vol. 53, No. 1, pp. 85-95.

Monadjemi, M. S. (1989), "Fiscal D eficits and Interest Rates: A Multi-Country Analysis", Australian EconmicPape, Vol. 28, No. 53, pp. 209-18.

Monadjemi, M. S. and Huh, H. (1998), "Private and Government Investment: A Study of Three OECS Countries", Intemational EconomicJarmal", Vol. 12, No. 2, pp. 93-105.

Mundell, R. A. (1963), "Capital Mobility and Stabilization Policy Under Fixed and Flexible Exchange Rates, Canadian Jaumal of Economics and Pditical Saience, Vol. 29, pp. 475-485.

Mussa, M. (1976), "The Exchange Rate, the Balance of Payments, and Monetary and Fiscal Policy Under a Regime of Controlled Floating", ScandinavianJamal of Econmics Vol. 78, pp. 229-254.

Mussa, M. (1986), "Nominal Exchange Rate Regimes and the Behaviour of Real Exchange Rates: Evidence and Implications", Conference Proceedings. Carnegie Rochester Conference Series on Public Policy, pp. 117-213. 
Nelson, M. A. and Singh, R. D. (1994), "The Deficit-Growth Connection: Some Recent Evidence from D eveloping Countries”, EconomicDedopment and Cultural Change Vol. 42, pp.167-191.

Patinkin, D . (1965), “, Money, Interest, and Prices", Second Edition, Harper and Row, Publishers, New York.

Penati, A. (1983), "Expansionary Fiscal Policy and the Exchange Rate: A Review”, IMF Staff Papers No. 30, Washington, D.C.

Perkins, J. O.N. (1997), “Budgt DefiatsandMacroeconomicPdia”, St. Martin’s Press, New Y ork.

Piersanti, G. (2000), "Current Account Dynamics and Expected Future Budget Deficits: Some International Evidence", Jaumal of intemational MoneyandFinance, Vol.19, No. 2, pp. 2555-71.

Plosser, C. I. (1982), “Government Financing Decisions and Asset Returns”, Jamal of Montary Econamics Vol. 9, No. 3, pp. 325-52

_ (1987), "Fiscal Policy and Term Structure", Jaumal of Mondary Economics Vol. 20, No. 2, pp. 343-68.

Premchand, A. (1984), "Govemment Budgting and Expenditure Contrds Theary and Practice', IMF, Washington, D.C.

Rao, V. K. R. V. (1953), "D eficit Financing, Capital Formation and Price Behaviour in an Underdeveloped Economy", Indian EcomomicReview Vol. 1, No. 3, pp. 55-91.

Rebelo, S. T. (1991), "Long-run Policy Analysis and Long-run Growth”, Jaumal of Pditical Economy, Vol. 99, pp. 500-21.

Roubini, N. and Sachs, J. (1989), "Political and Economic Determinants of Budget Deficits in the Industrial D emocracies”, Europen EcomamicReviex Vol. 33, pp. 903-938.

Sargent, T. and Wallace, N. (1981), "Some Unpleasant Monetarist Arithmetic", Quartery Review, Federal Reserve Bank of Minneapolis, No. 5, pp. 1-18.

Scarth, W. M. (1987), “Can Economic Make Monetarist Arithmetic Pleasant?”, Southern Economic Journal, Vol. 53, pp. 1028-1036.

Shojai, S. (ed.), (1999), “Budgt Defiats andDedt: A Gldbal Pespeetive”, Praeger Publishers, USA

Siddiqui, A. (1989), "The Causal Relation Between Money and Inflation in a D eveloping Economy”, Intemational EconomicJaumal, Vol. 3, pp. 79-96.

Smyth, D. and Hsing, Y. (1995), "In Search of An Optimal Debt ratio for Economic Growth", ContempararyEconamicPdig, Vol. XIII, No. 4, pp. 51-59.

Sowa, N. K. (1994), "Fiscal Deficits, Output Growth and Inflation Targets in Ghana”, Wordd Dedopment, Vol. 22, pp. 1105-1117.

Stoker, J. (1999), "The G overnment D eficit and the Exchange Rate”, Reviewof Intemational Economics Vol. 7, No. 4, pp. 753-63. 
Summers, H., (1986), "Issues in National Savings Policy" in F. Gerard Adams and Susan M. Wachter (eds.), "Savings andCapital Fomation", Mass.: Lexington Books, Lexington.

Swanson, P. E. and How, W. S. Y. (1986), "Portfolio Diversification by Currency D enomination: An Approach to International Cash management with Implications for Foreign Exchange Markets", QuartelyReviewofEconomics andBusiness Vol. 26, pp. 95-103.

Tallman, W. and Rosensweig (1991), "Investigations U.S. Government and Trade D eficits", Ecomamic Review(Federal Reserve Bank of Atlanta), pp. 1-11.

Tanzi, V. (1985), "Fiscal Deficits and Interest Rates in the U.S.: An Empirical Analysis, 1960-84", IMF Staff Papers Vol. 32, No. 4, pp. 551-76.

Thomas, L. B. and Abderrazak, A. (1988a), "Long-Term Interest Rates: The Role of Expected Budget D eficits", PublicFinanceQuartery, Vol. 16, No. 3, pp. 341-56.

. (1988b), "Anticipated Future Budget D eficits and Term Structure of Interest Rates", Sathem EconamicJaumal, Vol. 55, No. 1, pp. 150-61.

Tobin, J. (1969), “A G eneral Equilibrium Approach to Monetary Theory, Jaumal of Money, Creeit, and Banking Vol. 1, pp. 15-29.

Tran, D. T. and Swahney, B. L. (1988), "Government D eficits, Capital Flows, and Interest Rates", AppliedEconamics Vol. 20, No. 6, pp. 150-61.

Vamvoukas, G. A. (2000), "Short- and Long-Run Effects of Budget Deficits on Interest Rates", Spaudai, Vol. 50, No. 1-2, pp. 58-73.

Volcker, P. A. (1984), "Facing Up to the Twin D eficits", Challenge, pp. 4-9.

Volcker, P. A. (1987), "Facing Up to the Twin D eficits." in Fink, R. and High, J. (eds.), "A Nationin Debt: Economists DebatetheFederal Budge Defiat", Maryland: University Publications of America, Fredrick. pp. 154-161.

Wachtel, P. and Young, J. (1987), "D eficits Announcements and Interest Rates", AmmicanEconamic Review Vol. 77, No. 5, pp. 1007-12.

Y ellen, Janet L. (1989), "Symposium on the Budget D eficit", Jaumal of Econamic Pespeetives Vol. 3, No. 2, pp. 17-21.

Zahid, K. H. (1988), “Government Budget D eficits and Interest Rates: The Evidence Since 1971, Using Alternative D eficit Measures”, Sathem EconamicJaumal, Vol. 54, No. 3, pp. 725-731.

Zietz, J. and Pemberton, D. K. (1990), “The U.S. Budget and Trade Deficits: A Simultaneous Equation Model, Southern Economic Journal, Vol. 57, pp. 23-34. 